NBER WORKING PAPER SERIES

\title{
REDUCING INFORMATION FRICTIONS IN VENTURE CAPITAL: THE ROLE OF NEW VENTURE COMPETITIONS
}

\author{
Sabrina T. Howell \\ Working Paper 23874 \\ http://www.nber.org/papers/w23874 \\ NATIONAL BUREAU OF ECONOMIC RESEARCH \\ 1050 Massachusetts Avenue \\ Cambridge, MA 02138 \\ September 2017, Revised January 2018
}

Previously circulated as "Learning from Feedback: Evidence from New Ventures" and "Are New Venture Competitions Useful?" This project was generously funded by the Kauffman Foundation. For especially useful comments, I thank Manuel Adelino, Tom Åstebro, Tania Babina, Shai Bernstein, Edward Glaeser,Will Gornall, Boyan Jovanovic, Saul Lach, Augustin Landier, Josh Lerner, Song Ma, Holger Mueller, Ramana Nanda, David Robinson, Rick Townsend, Annette Vissing-Jørgensen, Ayako Yasuda, and participants at the NBER Entrepreneurship Working Group, Olin Corporate Finance Conference, Yale Junior Finance Conference, IDC Herzliya Eagle Labs Conference, Queens University Economics of Entrepreneurship and Innovation Conference, UC Berkeley- Stanford Innovation and Finance Conference, Georgia State CEAR Conference, and the Tech Scheller seminar. Finally, I thank Adam Rentschler of Valid Evaluation, and all the others who provided the data, including Lea Lueck, Allison Ernst, and Catherine Cronin. Lucy Gong, Sreyoshi Mukherjee, and Jack Reiss provided excellent research assistance. The views expressed herein are those of the author and do not necessarily reflect the views of the National Bureau of Economic Research.

NBER working papers are circulated for discussion and comment purposes. They have not been peer-reviewed or been subject to the review by the NBER Board of Directors that accompanies official NBER publications.

(C) 2017 by Sabrina T. Howell. All rights reserved. Short sections of text, not to exceed two paragraphs, may be quoted without explicit permission provided that full credit, including (C) notice, is given to the source. 
Reducing Information Frictions in Venture Capital: The Role of New Venture Competitions Sabrina T. Howell

NBER Working Paper No. 23874

September 2017, Revised January 2018

JEL No. G24,G4,L1,L2,L26,O3

\begin{abstract}
$\underline{\text { ABSTRACT }}$
Venture capital, an important source of financing for potentially high-growth new businesses, is believed to suffer from information frictions. This paper quantifies the magnitude of these frictions among participants in new venture competitions. In a regression discontinuity design with data from 87 competitions, winning a round increases the chances of external financing by about 35 percent. Winning is most impactful for ventures ranked just above the cutoff but that receive no cash prize, and judge ranks strongly predict venture success. The results indicate that information problems in new venture finance are large, and competitions can help resolve them through certification.
\end{abstract}

Sabrina T. Howell

NYU Stern School of Business

KMC 9-93

44 West 4th Street

New York, NY 10012

and NBER

showell@stern.nyu.edu

A online appendix is available at http://www.nber.org/data-appendix/w23874 


\section{Introduction}

Venture capital (VC) is a crucial resource for financing and nurturing potentially high growth but risky new ideas (Kaplan and Lerner 2010, Gornall and Strebulaev 2015). However, it suffers from information asymmetry between entrepreneurs and investors (Gompers and Lerner 2001, Ozmel, Robinson and Stuart 2013). Declining costs of starting a new venture may have intensified this problem over the past decade. ${ }^{1}$ Ewens, Nanda and Rhodes-Kropf (2018) document that lower barriers to entrepreneurial entry have created greater uncertainty about startup quality among earlystage VC investors. Yet there is little evidence about the size of information frictions or how consequential they might be in terms of startup real outcomes.

This paper uses data from new venture competitions to shed light on information frictions in new venture finance. In a competition, early-stage startup founders present their businesses to a panel of expert judges, whose scores determine which ventures win each round. Private ranking data permit a regression discontinuity design to estimate the effect of winning, independently of the effect of any cash prize. Specifically, the data include 87 competitions in 17 U.S. states between 2007 and 2015. The 4,328 participating ventures are linked to employment, financing, and survival outcomes. Founders are linked to education and career histories. There are no local subsistence businesses - such as restaurants or landscapers - that often contaminate efforts to study highgrowth entrepreneurship (Levine and Rubinstein 2016).

Within a competition-round, winning increases a venture's chances of raising subsequent external finance by between nine and 13 percentage points, relative to a mean of 24 percent, after controlling for any cash prize. The effect is robust to an array of alternative specifications,

\footnotetext{
${ }^{1}$ This is especially due to the advent of cloud computing. See Miller and Bound (2011), Economist (2014), Palmer (2012), and Ewens, Nanda and Rhodes-Kropf (2018). Y Combinator Founder Paul Graham (2013) wrote in 2008, "The other reason no one was doing quite what we do is that till recently it was a lot more expensive to start a startup." (http://paulgraham.com/ycombinator.html).
} 
including one with judge fixed effects. The most conservative estimates from preliminary rounds and among non-cash prize winners suggest an 8.5 percentage point effect, or 35 percent of the mean. This finding, which demonstrates that new venture competitions certify winning startups as higher quality for early-stage investors, offers a magnitude for information frictions among participating ventures.

New venture competitions are part of a larger phenomenon of new intermediaries that have emerged in the past two decades to support and finance early-stage startups, especially those founded by young, first-time entrepreneurs. These also include accelerators, incubators, and crowdfunding platforms. Accelerators have received some attention in the literature (Hochberg and Fehder 2015, Gonzalez-Uribe and Leatherbee 2017, and Yu Forthcoming). There are also studies of crowdfunding, including Mollick (2014) and Hildebrand, Puri and Rocholl (2016). In contrast, new venture competitions have received little academic attentions. They are now ubiquitous, organized by universities, governments, corporations, and other institutions around the world seeking to promote high-growth entrepreneurship.

Four findings strongly suggest that certification is the primary mechanism for the effect of winning on financing: (a) winning is impactful among marginal ventures; (b) winning has an effect independently of any effect of cash prizes; (c) winning is more impactful for Internet- or softwarebased ventures; and (d) judge scores and ranks are informative about outcomes. First, ventures of marginally investible quality should benefit from a quality signal. Consistent with this, the effect is larger (16-17 percentage points) using narrow bandwidths of one or two firms around the cutoff for winning. Further, winning a preliminary round but not a final round is at most only slightly less impactful than winning a final round. The quality distribution is wider in preliminary rounds, potentially making a signal more valuable. These results indicate that winning is impactful among ventures that the judges deem marginal. 
Second, it may be the case that winning is useful because cash prizes directly alleviate financial constraints. The data permit separately identifying the effect of the cash prize, as not all winners receive prizes and prize amounts vary within a competition. An additional $\$ 10,000$ in prize money increases the probability of subsequent financing by about four percent. However, this effect is not robust to all specifications. Further, the economic magnitude of the effect seems small: winning an average prize of $\$ 73,000$ has a smaller effect than winning only a preliminary round. More importantly, not only is winning a preliminary round but not a final round useful, but winning a final round is most useful to those winners that do not receive a cash prize. Top-ranked winners may be less financially constrained because they can send strong signals independently of the competition. These results suggest that the cash prize, which is awarded to the highest ranked winners, may to some degree crowd out private investment.

The relatively small effect of the cash prize is somewhat inconsistent with related studies in developing countries. For example, McKenzie (2017) finds that a Nigerian business plan competition cash prize has large, positive effects on firm outcomes. ${ }^{2}$ In the U.S. setting, prizes appear second-order to information effects, possibly reflecting the relative importance of information asymmetry in the U.S. context. In developing countries, startups may have to rely on internally generated funds because $\mathrm{VC}$ is absent altogether. They may also have business models, such as small-scale manufacturing, that require more initial fixed capital.

Related to this point, signaling may be more important when a venture's initial prototyping stage is not costly. This leads to the third piece of evidence for certification, that Internet- or software-based ventures, rather than hardware ventures, drive the effect of winning. Ewens, Nanda and Rhodes-Kropf (2018) show that low startup costs for Internet- or software-based ventures yield more marginal entrants and enable VCs to conduct more initial, high-risk funding experiments.

\footnotetext{
${ }^{2}$ Also see Klinger and Schündeln (2011) and Fafchamps and Quinn (2017).
} 
Therefore, generating a better signal by winning a competition should have a larger effect for Internet- or software-based ventures.

The final finding (d) is that consistent with an important role for information, the judge ranks are strongly predictive of success - proxied with venture financing, survival and employment - even in competitions where ventures do not learn their ranks and so cannot be affected by them. The effects of rank are large in magnitude. For example, a one decile improvement in rank is associated with a 1.8 percentage point increase in the chances of financing, which is more than the effect of an additional $\$ 10,000$ in cash prize. Overall ranks are aggregated from specific criteria ranks. Of these, the team criterion best predicts initial venture success, consistent with Gompers, Gornall, Kaplan and Strebulaev (2016) and Bernstein, Korteweg and Laws (2017). However, technology/product scores are strongly predictive - and are the only predictor - of long run, high-level success (acquisition/IPO). This speaks to the "horse vs. jockey" debate; team may matter most initially, but the business may matter most in the long run (see Kaplan, Sensoy and Strömberg 2009).

There are two alternative channels to certification. One is that the judges themselves are the subsequent investors in startups. If this were the case, competitions might reduce search costs through a convening function. However, in only 0.2 percent of judge-venture pairs did the judge or judge's firm invest in the venture. Controlling for this has no effect on the estimates. Second, the effect could reflect type revelation on the part of the entrepreneur. That is, the signal of winning may alleviate information problems for the entrepreneur rather than the investor. In this case, losing should lead to abandonment. However, the effect of winning on venture survival is much smaller than the effect on financing and is less robust.

Winning a competition seems to primarily serve a certification function, signaling quality to the market and reducing search frictions between VCs and entrepreneurs, in the sense of 
matching models such as Inderst and Müller (2004), Sørensen (2007), and Ewens, Gorbenko and Korteweg (2018). The results are consistent with VCs using new venture competitions to help identify promising startups, particularly among more marginal startups that may be just barely positive NPV investments and may have the greatest uncertainty.

The findings should be interpreted as applying to the type of startup that participates in a new venture competition. Unfortunately, it is difficult to assess representativeness, as there are no data available on the universe of new ventures at hazard of receiving external financing, especially with the requisite business and founder characteristics (an effort is made in Section 2.3). That said, it seems likely that the startups in this sample are relatively marginal, as the best networked or highest quality ideas might be expected to receive $\mathrm{VC}$ without additional intermediation. Also, as there are no comprehensive data on competitions, it is impossible to establish that the programs studied here, while diverse, are representative of the universe of competitions. With these caveats in mind, the results suggest that information frictions in early-stage startup finance are large. This paper builds on the literature on information asymmetry in VC, which includes Hellmann (2006), Lindsey (2008), Tian (2011), Cao (2018), and Hochberg, Serrano and Ziedonis (2018).

This paper also provides the first systematic, causal evaluation of whether and how U.S. new venture competitions are useful to participating startups. Given the substantial resources both money and time - that organizers and judges contribute to competitions, it is important to understand their effects. Beyond financing, this paper shows that winning affects real outcomes. It increases survival, having at least 10 employees, and the chances of an acquisition or IPO. This contributes to the literature evaluating programs and policies to encourage entrepreneurship, which includes Lach (2002), Klapper, Laeven and Rajan (2006), Howell (2017), Hombert, Schoar, Sraer and Thesmar (2016), and Barrows (2018), beyond the work cited above. ${ }^{3}$

\footnotetext{
${ }^{3}$ Barrows (2018) evaluates accelerators and competitions that use the YouNoodle platform. Comfortingly, he also finds positive effects of winning on firm outcomes. An advantage of the data in this paper is that they permit a
} 
The following section discusses the data, sample representativeness, and summary statistics. Section 3 presents the estimation strategy. Section 4 analyzes the effect of winning and Section 5 assesses the cash prize and certification as possible channels. Section 6 concludes.

\section{New venture competition data}

This section introduces the new venture competition data (Section 2.1) and presents summary statistics (Section 2.2). Startups and founders in the data are compared to the U.S. startup ecosystem in Section 2.3.

\subsection{The competitions}

New venture competitions, in which founders present (or "pitch") their technologies and business models to a panel of judges, have proliferated in the past decade. Sponsored by universities, foundations, governments, and corporations, among other institutions, competitions usually aim to serve convening, certification, education, and financing functions. They appear to now be an important part of the startup ecosystem, particularly for first-time founders. For example, among the 16,000 ventures that the data platform CB Insights reports received their first seed or Series A financing between 2009 and 2016, 14.5 percent won a competition. There are no data on the number of competitions in the world, but casual observation suggests that nearly every non-profit university sponsors at least one, and most U.S. state governments and many national governments provide public funds to support competitions. ${ }^{4}$

sharp regression discontinuity design. For the subset of firms with observed outcomes in Barrows (2018), there is no discontinuity in the probability of winning at the cutoff.

${ }^{4}$ For example, New York has at least three publicly funded competitions. Two examples of publicly funded competitions in this paper are the Arizona Innovation Challenge, which awards $\$ 3$ million annually, and the National Clean Energy Business Plan Competition, with $\$ 2.5$ million in allocated funding. On NY, see https://www.nypl.org/help/services/startup, http://queensstartup.org/, and http://www.binghamton- 
This paper uses data from 87 competitions between 2007 and 2016. The individual competitions are listed in Appendix Table A.1. Data from these competitions permit observing startups and their founders at an earlier stage, with greater granularity, and in a larger sample than prior studies. Further, unlike many data sources commonly used to study entrepreneurship, such as the Survey of Consumer Finances or the Panel Study of Income Dynamics, local subsistence businesses do not appear. The data were obtained individually by the author from program administrators who were either cold-called or previously known to the author and from Valid Evaluation, a company that provides application and judging software as a service. The competitions are therefore not randomly selected, but effort was made to include a variety of competition types. Some are organized by universities, which are clearly a major sponsor. The competitions are held in a variety of U.S. locations, including major hubs and areas without substantial entrepreneurial activity. There is no sense in which it is possible to assess whether the competitions are "representative," as there are no existing data on competitions (accelerator programs are substantively different).

All the competitions studied here have the following features: (1) They include a pitch event, where the venture presents its business plan for 5-15 minutes; (2) Volunteer judges privately score participants; (3) Venture ranks in the round determine which ventures win; (4) Ranks and scores are secret, except when a feedback competition privately informs a venture of its rank; (5) The organizer does not take equity in any participating ventures; (6) The organizer explicitly seeks to enable winners to access subsequent external finance. The competitions are usually open to the public, but typically there are few people besides the judges in the room, except in the final round. In most competitions, judges score or rank based on six criteria: Team, Financials, Business Model, Market Attractiveness, Technology/Product, and Presentation. These criteria scores or ny.gov/binghamton-local-development-corporation-bldc. 
ranks are aggregated into a judge-specific venture score or rank. When scores are used, they are ordered to produce ranks. Judge ranks are then averaged to create an overall rank, which determines round winners. The econometrician observes all ranking and scoring information. This includes overall ranks and individual judges' scores and ranks. In no case do founders observe individual judge scores or ranks. Judges score independently and observe only their own scoring, and never overall ranks. ${ }^{5}$ Winning participants are typically listed on a program website.

Summary statistics about the competitions are in Table 1 Panel 1. Competitions consist of rounds (e.g. semifinals), and sometimes judging occurs in panels within a round. The mean number of judges in a competition-round-panel is 17 . The median competition has two rounds. Within the 113 preliminary rounds, the average number of participating ventures is 45 . Within final rounds, this average is 19 . Importantly for the regression discontinuity design, there are multiple winners in most rounds, with a median of 11 winners in preliminary rounds and four in final rounds. The average prize is $\$ 73,000$, and ranges from $\$ 2,000$ to $\$ 275,000$. Only 64 percent of winners in final rounds receive cash prizes.

In 34 of the competitions, representing 35 percent of unique ventures, ventures receive an email after the round containing their overall and criteria ranks. Ventures learn only their own ranks, and not those of other participants. In the remaining 53 competitions, participants do not observe any rank information. There are no systematic differences in the way judges score or in services (e.g. mentoring, networking, or training) across the two competition types. In no case did a competition with feedback advertise itself as providing relative ranks or more feedback in general, so ventures with greater informational needs could not have selected into them. Judges were not informed that feedback would be provided, so there is no reason to believe they would exert greater effort in the feedback competitions. Judges also cannot learn from the feedback, as

\footnotetext{
${ }^{5}$ Judges could in theory report their scores to each other. This is unlikely, as 17 judges score a venture on average.
} 
they observe only their own scoring.

This paper uses four transformations of the rank and score data. The first measure is decile rank calculated for the round and within winners and losers separately. Decile ranks divide the group into ten equal bins, with the best ranks in decile one, and the worst in decile 10 . The second measure is rank centered around the cutoff for winning, so that a rank of one indicates the lowestranked winner, and a rank of negative one indicates the highest-ranked loser. For example, if there are four winners, the first-place winner will have a centered rank of four, and the second-place winner will have a centered rank of three. The third measure is judge decile rank, calculated among ventures that the judge scored. Finally, z-scores are calculated for the subset of competitions that begin with raw scores. The z-score indicates how far, in terms of standard deviations, a given absolute score falls relative to the sample mean. A higher z-score is better.

\subsection{Ventures, founders, and judges}

The 4,328 unique ventures are described in Table 1 Panel 2. Ventures were matched to investment events and employment using CB Insights, Crunchbase, AngelList, and LinkedIn. ${ }^{6}$ Care was taken to account for name changes, as early-stage startups often change their names. In researching the ventures, 765 name changes were identified. On average, 24 percent of participating ventures raise private investment (angel or venture capital) after the round. At the time of the competition, ventures are on average 1.9 years old, and 44 percent of them are incorporated as a C- or Scorp. $^{7}$ Thirty-five percent are located in either California, Massachusetts, or New York. Fifty-two

\footnotetext{
${ }^{6}$ The match rates for companies were 19 percent, 15 percent, 36 percent, and 45 percent, respectively. The match rate of founders to LinkedIn was 79 percent. For LinkedIn, only public profile data is used by non-logged-in users, based on Google searches for person and school or firm. VentureXpert was not used as it has poor coverage of very early-stage investment, and has not been found by the author to outperform the combination of the three datasets used here to identify external financing events.

${ }^{7} \mathrm{Age}$ is determined by the venture's founding date in its application materials. Ventures that describe themselves as "not yet founded" are assigned an age of zero.
} 
percent are known to have business models centered around the Internet or software. There are 558 ventures that participate in multiple competitions.

Venture survival, which averages 34 percent, indicates that the venture had at least one employee besides the founder on LinkedIn as of August 2016. While some startups may not initially appear on LinkedIn, if they are ultimately successful they almost certainly will, because their employees will identify themselves as working at the company. That is, companies rarely remain in "stealth" mode forever. This measure of survival is not ideal and induces truncation bias (mitigated by time fixed effects). However, it is the best available measure for very early-stage ventures. An obvious alternative, the presence of a website, is a poor survival measure because websites often stay active long after a venture has failed. An outcome variable that proxies for meaningful real economic activity is having at least 10 employees on LinkedIn as of August 2016, which averages 20 percent. Three percent of the sample experiences an acquisition or IPO, which represents right-tail success from the perspective of a very early-stage venture.

Founders are described in Table 1 Panel 3, using data from the competitions and LinkedIn profiles. Founders are mostly first-time entrepreneurs. Twenty-two percent of founders are women, and 73 percent are men (the remaining five percent have ambiguous names and no clear LinkedIn match). ${ }^{8}$ Age is calculated based on birth year, which is approximated as the college graduation year less 22. Eighteen percent graduated from a top 10 college (see Appendix Table A.2 for definitions), and 20 percent are students at the time of the competition. Almost half of founders have an MBA, and two-thirds of the MBAs are from top 10 programs.

Judges participate to source deals, clients, job opportunities, or as volunteer work. There are 2,514 unique judges, described in Appendix Table A.3, of whom 27 percent are VCs, 20 percent

\footnotetext{
${ }^{8}$ Genders were assigned to founder names using the Blevins and Mullen (2015) algorithm, based on gender-name combinations from the U.S. Social Security Administration. Unclear cases, such as East Asian names, were coded by hand.
} 
are corporate executives, and 16 percent are angel investors. Ventures and judges are assigned to 16 sectors. Sector assignations come from competition data, and each venture is assigned only one sector. Judge sectors are drawn from LinkedIn profiles or firm webpages, and judges may have expertise in multiple sectors. Ventures and competitions are sorted by state in Appendix Table A.4. There is concern that the judges investing themselves might contaminate any impact of the competitions on venture financing. Careful comparison of funded ventures' investors and judges revealed 95 instances of a judge's firm invested in the venture, and three instances of a judge personally investing.

These data shed new light on venture and founder characteristics associated with startup success. In Appendix Table A.5, subsequent financing and having at least 10 employees are projected on characteristics. More founder job experience, being an Internet or software venture, being located in a $\mathrm{VC}$ hub state, and having prior financing are all strongly associated with success. Having an MBA is negatively associated with success. This relationship is weak for financing, but column 4 suggests that founders with MBAs are 5.4 pp (27 percent of the mean) less likely to have at least 10 employees, significant at the 0.01 level. Conversely, attending a top 10 college is associated with a higher likelihood of investment. Kaplan, Klebanov and Sorensen (2012) find a similar relationship between college selectivity and success for CEOs of VC-backed companies. $^{9}$

\subsection{Sample representativeness}

There is little existing empirical analysis of startups before their first external funding event. Therefore, there are no obvious benchmarks against which to assess whether the participating ventures are representative. However, an attempt is made to compare the startups in this sample to

\footnotetext{
${ }^{9}$ A similar exercise using founder college majors does not find strong variation. Majoring in either entrepreneurship or political science/international affairs is weakly associated with success.
} 
other data about first-time, early-stage U.S. startups and their founders. Appendix Table A.6 compares the distribution of ventures to overall U.S. VC investment. The share of software startups, 37 percent, is close to the national average of 40 percent in both deals and dollars. In part because VC investment in clean energy has declined dramatically in recent years (Saha and Muro 2017), as well as the presence of the Cleantech Open competition, the data are skewed towards clean energy.

The competitions take place in 17 U.S. states. With the exception of Arizona, the top 20 states for venture location in the data almost entirely overlap with the top 20 states for VC investment, though the data has fewer ventures from California and more from Massachusetts. This may be expected from early-stage ventures, as startups often move to Silicon Valley to raise VC. The probability of an IPO or acquisition, three percent, is comparable to the five percent found in Ewens and Townsend (2017)'s sample of AngelList startups. Ventures average three team members, similar to the 2.6 founders on the AngelList platform in Bernstein, Korteweg and Laws (2017). The median founder age is 29 years, which is roughly representative of startup founders. ${ }^{10}$

\section{Estimation strategy}

A regression discontinuity (RD) design permits establishing a causal effect of winning a competition. Estimation is based on Equation 1.

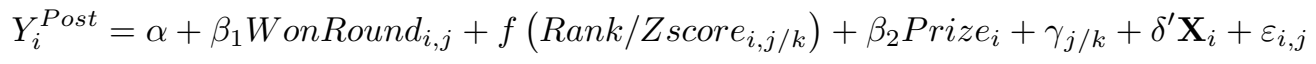

The dependent variable $Y_{i}^{\text {Post }}$ is a binary measure of venture $i$ 's success. A function of rank or z-score is at the competition-round-panel $(j)$ or judge $(k)$ level. Prize $e_{i}$ is the dollar amount

\footnotetext{
${ }^{10}$ The average Y-Combinator founder is just 26, and the average entrepreneur age at company founding among startups with at least a \$1 billion valuation between 2003 and 2013 was 34 (https://techcrunch.com/2010/07/30/ronconway-paul-graham/ and https://techcrunch.com/2013/11/02/welcome-to-the-unicorn-club/).
} 
that the venture won, if any. Fixed effects for either the competition-round-panel $\left(\gamma_{j}\right)$ or judge $\left(\gamma_{k}\right)$ are included. The former absorb the date and location. Venture controls $\mathbf{X}_{\mathbf{i}}$ include whether the company received investment before the round, whether any of the venture's judges or those judges' firms ever invested in the venture, 17 sector indicator variables, company age, and whether the founder is a student. These, especially age, reduce the sample size and are not included in most specifications. Standard errors are clustered by competition-round-panel or by judge.

A valid RD design requires that treatment not cause rank. This is not a problem here, as the award decision happens after ranking. One way this setting differs from a conventional RD design is that the ranking is ordinal rather than cardinal. This is similar to the ordinal ranking used in an RD design in Howell (2017); in both settings, the differences in the true distance between ranks should be the same on average. That is, errors in differences on either side of cutoff in any given competition should average out. To address any concerns with an ordinal running variable, z-scores based on nominal scores are employed in an alternative specification.

The rating variable is also discrete - the average number of participants is 45 for preliminary rounds, and 19 for final rounds. This discreteness is less severe than that in Howell (2017), where there are on average 10 applicants per grant competition. Lee and Card (2008) note that the fundamental econometrics are not different with a discrete rating variable, even if there is greater extrapolation of the outcome's conditional expectation at the cutoff. To determine the appropriate polynomial, the goodness-of-fit test for RD with discrete covariates from Lee and Card (2008) is employed, which compares unrestricted and restricted regressions. ${ }^{11}$ Also note that a McCrary (2008) test for density around the cutoff is not relevant here, since by definition the

\footnotetext{
${ }^{11}$ The unrestricted projects the outcome on dummies for each of $K$ ranks. The restricted is a polynomial like Equation 1. The goodness-of-fit statistic is: $G \equiv \frac{\left(E S S_{R e s t r .}-E S S_{U n r e s t r .}\right) /(K-P)}{E S S_{U n r e s t r .}(N-K)}$, where $E S S$ is the error sum of squares from regression, $N$ is the number of observations, and $P$ is the number of restricted parameters. $G$ takes an F-distribution. The null hypothesis is that the unrestricted model does not provide a better fit. If $G$ exceeds its critical value, the null is rejected in favor of a higher order polynomial.
} 
ranks around the cutoff are populated equally.

The primary empirical concern is whether ranks are manipulated around the cutoff, because the cutoff in a valid RD design must be exogenous to rank (Lee and Lemieux 2010). That is, the identification strategy is threatened if judges or organizers sort ventures on unobservables around the cutoff. This is extremely unlikely because judges score independently and typically only score a subset of participating ventures. Scores are then averaged and sorted to create ranks, as explained in Section 2.1.

Reassuringly, observable baseline covariates and pre-assignment outcome variables are smooth around the cutoff using both decile ranks and centered ranks. This is shown with decile ranks in Figure 1 for venture variables observable at the time of the competition, such as previous financing and whether the venture is incorporated. Similarly, Figure 2 shows that founder characteristics observable at the time of the competition, such as having a BA from a top 10 college, being female, and the number of previous jobs, are continuous across winners and losers. The figures use final rounds and decile ranks. They are similar when preliminary rounds or centered rank are used instead. Note that with decile rank, the winner and loser local polynomial lines overlap because the winning share varies across rounds. ${ }^{12}$

\section{Effect of winning}

\subsection{Effect of winning on subsequent financing}

Visual evidence of the effect of winning is in Figures 3 (using decile ranks) and 4 (using centered ranks around the cutoff). In each case, the top two graphs show the probability of subsequent external financing in preliminary and final rounds. The middle two graphs show the probability of

\footnotetext{
${ }^{12}$ There are no losers in the top bin, and winners are truncated at the fifth decile.
} 
venture survival, and the bottom two graphs show the probability of having at least 10 employees. The positive effect of winning is apparent in all cases, especially for preliminary rounds. In the decile graphs, the winner line lies above the non-winner line, and in the cutoff graphs, there is a clear discontinuous jump at the cutoff. This provides strong evidence of a substantial raw effect of winning.

Regression estimates of the effect of winning are in Table 2, using variants of Equation 1. The dependent variable is subsequent external financing. Final and preliminary rounds are included. Further, some ventures participate in multiple competitions, and all observations are included. Thus, in this main specification, a venture can appear multiple times. Using overall decile rank in the round, winning a round increases a venture's chances of subsequent external finance by 8.8 percentage points (pp), relative to a mean of 24 percent. The preferred specification in column 2, where decile ranks on either side of the cutoff are used, finds an effect of $13 \mathrm{pp}$. When a rich array of venture controls is added (substantially decreasing the sample size), the effect is 7.9 pp (column 3).

Equation 1 is estimated at the judge-venture level in Table 2 Panel 1 column 4. That is, each observation is a judge's rank of the venture within a competition-round-panel. This model includes judge fixed effects and controls for the venture's decile rank within ventures that the judge scored. Year fixed effects are also included. Note that judges often participate in multiple rounds and in some cases are observed in multiple competitions, so judge fixed effects are quite different from the competition-round-panel fixed effects used in other specifications. This model finds a larger effect of winning, at $17 \mathrm{pp}$. Standard errors are clustered by judge, but the standard error is essentially unchanged when clustering by venture.

Subsequent specifications use alternative controls. Table 2 Panel 1 column 5 uses z-scores and so is restricted to the subsample of competitions that use scores before force-ranking 
participants. Panel 2 columns 1-3 use various forms of centered rank around the cutoff. In columns 1-2, linear and quadratic centered rank yield the same effect as the main specification. The goodness of fit test discussed in Section 3 finds that linear rank is optimal. When centered rank is controlled for separately among winners and losers, the effect is somewhat larger (column 3).

To assess the effect of winning near the cutoff, Table 2 Panel 2 columns 4-7 use narrow bandwidths. When only one venture on either side of the cutoff is included, the effect is $16 \mathrm{pp}$. It is $11 \mathrm{pp}$ when cash prize winners are excluded (column 5). With two ventures on either side of the cutoff, the effect is $14 \mathrm{pp}$ overall and $8.6 \mathrm{pp}$ without prize winners (columns 6-7). The differences between the estimates with and without winning a prize are not significantly different from one another.

\subsection{Effects by round type}

In order to shed light on the mechanism, it is useful to decompose the overall effect of winning into that of the cash prize and the type of round (preliminary or final). It is possible to identify the prize separately from winning for two reasons. First, as mentioned in Section 2.1, only 64 percent of winners in final rounds receive cash prizes. Second, the prize amount typically varies across winners that do win cash prizes within a final round. The average standard deviation of prize money within final round prize winners is $\$ 12,300$. While prize amounts may vary with competition characteristics, competition fixed effects absorb this variation. The regressions in Table 2 consistently find that an extra $\$ 10,000$ increases the probability of financing by nearly 1 pp. This implies that the average prize of $\$ 73,000$ increases the chances of financing by $7.3 \mathrm{pp}$. The effect of cash prizes appears linear, as there is no effect of higher order functions of the prize, such as the prize squared. 
This positive effect of a cash prize is smaller than the effect of winning even a preliminary round and is not as robust. Table 3 column 1 includes dummies for winning a preliminary round, a final round, and a prize. Note that for prize winners, all three of these will equal one. The effect of winning a preliminary round after controlling for winning the final round is $8.1 \mathrm{pp}$. The prize indicator has a near-zero and insignificant coefficient. Columns 2 and 3 establish this more rigorously by restricting the sample to final rounds. The effect of winning is $12 \mathrm{pp}$, and there is no effect of an additional $\$ 10,000$ in cash prize (column 2). When prize winners are excluded from the sample, and the point estimate of winning a final round rises to $17 \mathrm{pp}$ (column 3). This indicates that the effect of winning a final round is driven by marginal winners that do not win a cash prize.

The sample is restricted to preliminary rounds in Table 3 columns 4-6. The effect of winning a preliminary round is $14 \mathrm{pp}$ (column 4), which is slightly higher than the overall effect using all rounds with the same specification in Table 2 column 2. After controlling for whether the venture won the final round (column 5) the effect of a preliminary win is $8.6 \mathrm{pp}$. It is $8.5 \mathrm{pp}$ when final round winners are excluded from the sample (column 6). The difference between the coefficients on winning final and preliminary rounds is significant at the .05 level in column 5. Note, however, that both coefficients on winning are relative to preliminary round losers. Winning a preliminary round but not a final round is at most only somewhat less useful than winning a final round (8.6 pp vs. $12 \mathrm{pp}$, which are not significantly different from one another). In sum, winning a cash prize is useful, but is not nearly as useful as winning the round.

\subsection{Effect of winning on real outcomes}

Real startup outcomes - survival, having at least 10 employees, and being acquired or going public - are considered in Table 4 . The first four columns use the whole sample, the next three preliminary 
rounds, and the final three a bandwidth of two ventures on either side of the cutoff. First, consider the probability of venture survival. Winning has a $4.7 \mathrm{pp}$ effect across all rounds, though this is significant only at the .1 level (column 1). It loses significance in preliminary rounds but is a robust $7.7 \mathrm{pp}$ with the narrow bandwidth (column 8 ). There may be concern that dead ventures are miscoded and in fact reflect a "pivot" and venture name change. As mentioned above, care was taken to identify name changes. Nonetheless, some miscoding may remain. Therefore, column 2 considers founders that subsequently founded or were the CEO of a different company, in case these other companies are in fact the original ventures with new names. There is no effect of winning. This not only serves as a robustness test, but also indicates that winning does not affect entrepreneurship as a career for the founder, despite being useful for the venture.

Having at least 10 employees is a measure of real economic activity. In the context of earlystage ventures, it is a meaningful marker of success. The bottom two graphs in Figures 3 and 4 show a clear jump at the cutoff in preliminary rounds, indicating a significant effect of winning. Winning increases the chances of having at least 10 employees by 5.1 pp across all rounds, and $6.3 \mathrm{pp}$ in preliminary rounds (Table 4 columns 3 and 6). It has a similar effect using the narrow bandwidth, of $5.9 \mathrm{pp}$ (column 9). There are not many acquisitions or IPOs in the data; the mean is just three percent. The effect of winning on these successful exits is not quite significant in all rounds or with the narrow bandwidth (columns 4 and 10), but it is $2.6 \mathrm{pp}$ in preliminary rounds (column 7). At almost 100 percent of the mean, this effect is large in economic magnitude. For all outcomes in Table 4, the results are similar with controls for centered rank.

\subsection{Effect of rank}

A striking finding from Tables 2-4 is that rank and score strongly predict success after controlling for winning and competition fixed effects. For example, a one decile improvement in rank among 
losers is associated with a $1.8 \mathrm{pp}$ increase in the probability of external financing, which is 7.5 percent of the mean (Table 2 Panel 1 column 2). Individual judge ranks are also predictive within judge (Table 2 Panel 1 column 4). Importantly, the effect of rank persists within the no-feedback competitions, where ranks cannot directly affect venture outcomes (Table 6 Panel 1 column 6).

The criteria ranks are also informative. Table 5 shows the association between criteria ranks and outcomes, controlling for win status. A higher team rank (i.e. the quality of the founders) is the strongest predictor of success for all outcomes except IPO/acquisition. Similarly, Bernstein, Korteweg and Laws (2017) and Gompers, Gornall, Kaplan and Strebulaev (2016) find that earlystage investors care most about information regarding founder team quality. For IPO/acquisition, the only criterion with predictive power is product/technology, and this is quite robust. Therefore, in these data, team is most relevant for low-level, early-stage success, while technology matters most for high-level, late-stage success. This speaks to the "horse vs. jockey" debate, suggesting that the team matters initially, but the business matters in the long run. It is consistent with Kaplan, Sensoy and Strömberg (2009), who examine 50 public firms and find that business lines but not management remain stable from startup to IPO.

The strong predictive power of rank found here contrasts with the U.S. Department of Energy ranks of SBIR grant applicants in Howell (2017), which are uninformative about firm outcomes. There are a number of differences between the SBIR grant process and new venture competitions. One is that competition judges tend to be expert market participants rather than government officials. Nearly half of the judges in these data are angel or VC investors (Appendix Table A.3). Unreported regressions examine the predictive power of rank by judge occupation. There is little difference across investor, lawyer/consultant/accountant, and corporate executive judges. Perhaps surprisingly, entrepreneur judges are the exception: their scores have no predictive power. There is no relationship between judge-venture sector match and the predictive 
power of judge ranks.

\subsection{Robustness tests}

Robustness tests confirm the main effect of winning and find it to be consistent across relevant subsamples. In Table 6 column 1, errors are clustered by competition rather than competition-round-panel. Venture or judge clusters also yield similar results to the main model (unreported). In column 2, ventures in which a judge or judge's firm invested are excluded, in case these judges' favorable opinion of the ventures mechanically causes winning or rank to predict financing. Column 3 restricts observations to a venture's first competition. Column 4 uses a logit model instead of OLS and finds that winning doubles the odds of receiving financing. Note that logit is not preferred as it drops groups without successes (i.e. panels without ventures that subsequently received financing). Column 5 restricts the sample to competitions that gave participants feedback by informing them of their rank in the round, while column 6 restricts the sample to competitions that did not provide feedback. The effect is somewhat larger in the no-feedback competitions, at .17 pp, though the difference is not statistically significant.

The main model uses competition fixed effects, so the results should not be affected if participants are on average higher quality in some competitions. However, to ensure robustness and explore potential heterogeneity, Table 6 Panel 2 divides the sample by competition type. The effect is 12 (15) pp in competitions not held at (held at) universities (columns 1-2). The effect is unchanged when the two largest competitions are excluded (HBS New Venture Competition in column 3 and Arizona Innovation Challenge in column 4). The effect is very similar to the main result when small competitions (less than 30 participants) are excluded (column 5).

The final columns of Table 6 Panel 2 divide the sample by venture and founder characteristics. The effect is robust to restricting the sample to ventures located in California, 
Massachusetts, and New York (column 6), to incorporated ventures (column 7), to founders with MBAs (column 8), and to student founders (column 9).

Judge ranks remain predictive of outcomes in all cases except among founders with MBAs. They are most predictive for incorporated ventures, which may be easier to assess because they are more mature. The above robustness tests for winning in Table 6 go through for survival and 10+ employees; these are available on request. With the exception of technology type (discussed below), the remarkable consistency of the effect across subsamples indicates that conditional on selecting into participating in a competition, winning provides ventures with roughly homogenous benefits.

\section{Interpretation}

\subsection{Channel 1: Cash}

Non-dilutive cash may directly alleviate financing constraints. Founders could, for example, use it to build initial prototypes of their products, which might reduce uncertainty about the startup among prospective investors. Cash could also improve the bargaining position of the entrepreneur or reduce the amount of outside equity needed. Indeed, independently of winning, the cash prize is useful, with positive effects on financing, survival, and employment (Tables 2 and 4).

Yet the effect is economically small relative to the effects of winning either a preliminary or final round, and the effect of winning a final round is stronger among winners that do not receive a prize. The effect of the cash prize is also small relative to the predictive power of rank. Even in the specification where it has the largest, most robust coefficients, the effect of an additional $\$ 10,000$ is similar to or smaller than one decile of rank's predictive power. It is also smaller in economic magnitude than the effect of U.S. Department of Energy SBIR grants found in Howell (2017). The 
effect of an additional $\$ 10,000$ in SBIR grants on the probability of subsequent financing is 0.66 $\mathrm{pp}$, or eight percent of the sample mean, compared to about one pp, or four percent of the sample mean, for the same amount of competition prize money. ${ }^{13}$

Heterogeneity in the effect of the cash prize exists for two variables and suggests that the cash prize is more impactful among more financially constrained ventures. Table 7 interacts all covariates except the competition fixed effects with a characteristic $C$. Column 1 shows that the cash prize has a significantly smaller effect for founders with elite college degrees. ${ }^{14}$ Column 2 shows that the cash prize has a significantly smaller effect for founders who were previously was the $\mathrm{CEO}$ or founder of a different venture (i.e., serial entrepreneurs). Founders with top college degrees are likely wealthier (Chetty, Friedman, Saez, Turner and Yagan 2017) and may have superior access to investor networks. The sensitivity of non-elite college founders' venture outcomes to cash suggests that cash prizes may help to level the entrepreneurship playing field. Serial entrepreneurs also may have better access to investor networks and may have accumulated capital from the previous venture. Both these types of founders are likely less financially constrained.

\subsection{Channel 2: Certification}

Winning could be an informative signal to the market, especially to early-stage investors. If certification is the primary mechanism for the positive effect of winning on financing and real outcomes, it should be the case that:

\footnotetext{
${ }^{13} \mathrm{~A} \$ 150,000$ SBIR grant increased the probability a venture subsequently received external financing by about $10 \mathrm{pp}$. Thus an extra $\$ 10,000$ in SBIR grants was associated with a $0.66 \mathrm{pp}$ increase in financing, while in the competition context an extra $\$ 10,000$ is associated with about a $1 \mathrm{pp}$ increase. The sample means are eight and 24 percent, respectively.

${ }^{14}$ The definition of "elite" is the top ten colleges (Appendix Table A.2). The result is robust to only using HarvardStanford-MIT, or the top twenty colleges.
} 
1. Winning has a strong effect independent of any cash prize effect;

2. Judge scores and ranks are informative about outcomes;

3. Winning is impactful among marginal ventures;

4. Winning is more impactful for Internet- or software-based ventures.

The first two are the most important, and the second two are ancillary. The evidence is consistent with the first hypothesis. Table 3 shows that winning has an effect separately from the prize. Moreover, winning a final round is more impactful among winners that do not receive a cash prize (Table 3 column 3). Further, winning an average prize of $\$ 73,000$ has a smaller effect than winning only a preliminary round. Finally, while the cash prize has a positive effect in some specifications, it is not robust across models (e.g. Table 3 columns 1,2, and 5). The cash prize, which is awarded to the highest ranked winners, may to some degree crowd out private investment.

Second, since winning is a binary transformation of judge ranks, rational investors should perceive winning as a quality signal only if the aggregated opinion of the judges is informative about venture outcomes. As explained in Section 4.4, the judge ranks are strongly predictive of success, even in competitions where ventures do not learn their ranks and so cannot be affected by them. This is consistent with an important role for information in how the competitions are useful.

The third hypothesis is that a quality signal should be impactful for marginal ventures that are not clearly positive NPV investments. Two findings are consistent with this. First, the effect is larger (16-17 pp) using narrow bandwidths of one or two firms around the cutoff for winning. This means that the effect is larger for firms that just barely won, relative to higher ranked winners. These results indicate that ventures of more marginal quality in the vicinity of the cutoff benefit most from winning, rather than the effect being consistent among lower- and higher-ranked winners. Second, information asymmetry between ventures and investors is likely 
higher in preliminary rounds. There should be more uncertainty about quality for preliminary round participants because they include all finalists as well as a left tail of lower-quality ventures. However, preliminary round winners are less observable, which should be expected to temper potential certification. Table 3 demonstrates that winning a preliminary round is independently very useful. Winning a preliminary round but not a final round is at most only slightly less useful than winning a final round (the difference between 8.6 and $12 \mathrm{pp}$ in columns 2 and 5). These results point to winning having an effect for those ventures that the judges deem marginal.

The last hypothesis is that certification from winning should be more impactful among Internet- or software-based ventures. There are two reasons, both of which emerge from the theory and findings in Ewens, Nanda and Rhodes-Kropf (2018). First, the low costs of starting an Internetor software-based venture should increase entry, resulting in more marginal entrants. Second, precisely because it is cheaper to experiment in funding these sorts of ventures, investors can more readily pursue a "spray and pray" strategy with minimal due diligence than they can with hardware startups that require large initial investments. Therefore, the signal of winning a competition, which is essentially costless for the VC to acquire, is likely to be more impactful. Table 7 column 3 shows that the main effect of winning is driven by Internet- or software-based ventures. The cash award is not more or less helpful for these ventures.

There are two alternative explanations for the effect of winning. First, it may be that the investors driving the main effect are the judges themselves; recall that about half of judges are angel or VC investors. If this were the case, the competitions might reduce search costs through a convening function. However, as Appendix Table A. 3 shows, in only 0.2 percent of judge-venture pairs did the judge or judge's firm invest in the venture. Further, as mentioned above, controlling for the judge or judge's firm investing has no effect on the estimate. Second, it is possible that the effect could reflect type revelation on the part of the entrepreneur. If an entrepreneur is uncertain 
about the quality of his own venture, he might perceive winning as a positive signal and be more likely to continue rather than abandon the venture. If this is the case, it means that the certification function serves to alleviate information problems for the entrepreneur as well as (or in lieu of) the investor. However, the effect of winning on venture survival is much smaller than the effect on financing, at about 14 percent of the mean (Table 4 column 1), relative to 54 percent for financing (Table 2 column 2). This suggests that the effect of winning is primarily to reduce information asymmetry with investors.

In sum, the large effect of winning independent of the cash prize effect and fact that ranks are informative indicate that competitions produce valuable signals to early-stage investors about venture quality. While certification may not be the only way that competitions are useful to entrepreneurs, it is an important mechanism driving the effect. Using the most conservative estimates from preliminary rounds and non-prize winners, the effect of certification is between 8 and $9 \mathrm{pp}$, or a 35 percent increase relative to the mean of 24 percent (Table 2 Panel 1 column 6, and Table 4 columns 1, 5, and 6). This contrasts with the finding in Howell (2017) that SBIR grants do not serve a certification function, and instead appear useful because the cash award funds prototyping. In the competition context, winning has a larger effect among winners that do not receive a cash prize. Top-ranked winners can send strong signals independently of the competition and so are likely less financially constrained.

\section{Conclusion}

In the presence of asymmetric information and search costs, it is difficult for VCs to identify the most promising early-stage startups. As the barriers to entry have fallen, especially for Internetand software-based ventures, new intermediaries are screening and offering support to very early- 
stage startups. Such intermediaries could serve an information provision function, filling a gap that may have emerged as some VCs either shift to later stages of the startup lifecycle or do less independent due diligence. In the context of competitions, an important new intermediary, this paper demonstrates the large magnitude of information frictions in early-stage startup financing. It shows that new venture competitions help identify promising ventures by certifying winning ventures as high quality. Marginal winners benefit a lot, consistent with being the ventures for which information asymmetry is a binding constraint on financing.

This paper also provides the first systematic, causal evaluation of whether and how new venture competitions are useful to participating startups. Winning has economically significant positive effects on subsequent financing, employment, and successful exit (acquisition/IPO). Notably, winning is quite useful in preliminary rounds and is most useful among those final round winners that do not receive cash prizes. Cash prizes are useful, but their effect is small relative to the effect of winning and the predictive power of rank. These results have implications for competition organizers. Rather than focusing on large cash prizes, competitions might consider directing resources to improving the quality of judging and market signaling. 


\section{References}

Barrows, G. (2018), Do entrepreneurship policies work? evidence from 460 start-up program competitions across the globe, Technical report.

Bernstein, S., Korteweg, A. and Laws, K. (2017), 'Attracting early-stage investors: Evidence from a randomized field experiment', The Journal of Finance 72(2), 509-538.

Blevins, C. and Mullen, L. (2015), 'Jane, John... Leslie? A historical method for algorithmic gender prediction', Digital Humanities Quarterly 9(3).

Cao, R. (2018), 'Information frictions in new venture finance: Evidence from product hunt rankings', Working Paper .

Chetty, R., Friedman, J. N., Saez, E., Turner, N. and Yagan, D. (2017), 'Mobility report cards: The role of colleges in intergenerational mobility'.

Economist (2014), 'A cambrian moment', Special Report . https://www.economist.com/specialreport/2014/01/17/a-cambrian-moment.

Ewens, M., Gorbenko, A. S. and Korteweg, A. (2018), 'Venture capital contracts'. Working paper.

Ewens, M., Nanda, R. and Rhodes-Kropf, M. (2018), 'Cost of experimentation and the evolution of venture capital', Journal of Financial Economics 128(3), 422-442.

Ewens, M. and Townsend, R. R. (2017), 'Investors and the entrepreneurship gender gap'. Working Paper.

Fafchamps, M. and Quinn, S. (2017), 'Aspire', The Journal of Development Studies 53(10), 1615-1633.

Gompers, P., Gornall, W., Kaplan, S. N. and Strebulaev, I. A. (2016), 'How do venture capitalists make decisions?'. National Bureau of Economic Research.

Gompers, P. and Lerner, J. (2001), 'The venture capital revolution', Journal of economic perspectives 15(2), 145-168.

Gonzalez-Uribe, J. and Leatherbee, M. (2017), 'The effects of business accelerators on venture performance: Evidence from start-up chile', The Review of Financial Studies 31(4), 1566-1603.

Gornall, W. and Strebulaev, I. A. (2015), 'The economic impact of venture capital: Evidence from public companies', Working Paper.

Hellmann, T. (2006), 'Ipos, acquisitions, and the use of convertible securities in venture capital', Journal of Financial Economics 81(3), 649-679.

Hildebrand, T., Puri, M. and Rocholl, J. (2016), 'Adverse incentives in crowdfunding', Management Science 63(3), 587-608.

Hochberg, Y., Serrano, C. J. and Ziedonis, R. H. (2018), 'Patent collateral, investor commitment, and the market for venture lending', Journal of Financial Economics .

Hochberg, Y. V. and Fehder, D. C. (2015), 'Accelerators and ecosystems', Science 348(6240), 1202-1203.

Hombert, J., Schoar, A., Sraer, D. and Thesmar, D. (2016), 'Can unemployment insurance spur 
entrepreneurial activity? evidence from france'. Working Paper.

Howell, S. T. (2017), 'Financing innovation: Evidence from R\&D grants', The American Economic Review 107(4), 1136-1164.

Inderst, R. and Müller, H. M. (2004), 'The effect of capital market characteristics on the value of start-up firms', Journal of Financial Economics 72(2), 319-356.

Kaplan, S. N., Klebanov, M. M. and Sorensen, M. (2012), 'Which CEO characteristics and abilities matter?', The Journal of Finance 67(3), 973-1007.

Kaplan, S. N. and Lerner, J. (2010), 'It ain't broke: The past, present, and future of venture capital', Journal of Applied Corporate Finance 22(2), 36-47.

Kaplan, S. N., Sensoy, B. A. and Strömberg, P. (2009), 'Should investors bet on the jockey or the horse? evidence from the evolution of firms from early business plans to public companies', The Journal of Finance 64(1), 75-115.

Klapper, L., Laeven, L. and Rajan, R. (2006), 'Entry regulation as a barrier to entrepreneurship', Journal of financial economics 82(3), 591-629.

Klinger, B. and Schündeln, M. (2011), 'Can entrepreneurial activity be taught? quasi-experimental evidence from central america', World Development 39(9), 1592-1610.

Lach, S. (2002), 'Do r\&d subsidies stimulate or displace private $r \& d$ ? evidence from israel', The journal of industrial economics 50(4), 369-390.

Lee, D. S. and Card, D. (2008), 'Regression discontinuity inference with specification error', Journal of Econometrics 142(2), 655-674.

Lee, D. S. and Lemieux, T. (2010), 'Regression discontinuity designs in economics', Journal of economic literature 48(2), 281-355.

Levine, R. and Rubinstein, Y. (2016), 'Smart and illicit: Who becomes an entrepreneur and does it pay?', The Quarterly Journal of Economics .

Lindsey, L. (2008), 'Blurring firm boundaries: The role of venture capital in strategic alliances', The Journal of Finance 63(3), 1137-1168.

McCrary, J. (2008), 'Manipulation of the running variable in the regression discontinuity design: A density test', Journal of econometrics 142(2), 698-714.

McKenzie, D. (2017), 'Identifying and spurring high-growth entrepreneurship: experimental evidence from a business plan competition', American Economic Review 107(8), 2278-2307.

Miller, P. and Bound, K. (2011), The Startup Factories: The rise of accelerator programmes to support new technology ventures, NESTA Discussion Paper.

Mollick, E. (2014), 'The dynamics of crowdfunding: An exploratory study', Journal of business venturing 29(1), 1-16.

Ozmel, U., Robinson, D. T. and Stuart, T. E. (2013), 'Strategic alliances, venture capital, and exit decisions in early stage high-tech firms', Journal of Financial Economics 107(3), 655-670. 
Palmer, M. (2012), 'Cloud computing cuts start-up costs', Financial Times .

Saha, D. and Muro, M. (2017), 'Cleantech venture capital: Continued declines and narrow geography limit prospects', Brookings Institution Report .

Sørensen, M. (2007), 'How smart is smart money? a two-sided matching model of venture capital', The Journal of Finance 62(6), 2725-2762.

Tian, X. (2011), 'The causes and consequences of venture capital stage financing', Journal of Financial Economics 101(1), 132-159.

Yu, S. (Forthcoming), 'How do accelerators impact the performance of high-technology ventures?', Management Science . 


\section{Table 1: Summary Statistics}

\begin{tabular}{|c|c|c|c|c|c|c|}
\hline \multicolumn{7}{|c|}{ Panel 1: Competitions } \\
\hline & $\mathrm{N}$ & Mean & Median & S.d. & Min & Max \\
\hline \# competitions & 87 & & & & & \\
\hline \# competition-rounds & 200 & & & & & \\
\hline \# competition-round-panels & 454 & & & & & \\
\hline \# competitions with feedback & 34 & & & & & \\
\hline \# rounds per competition & 87 & 2 & 2 & .69 & 1 & 3 \\
\hline \# ventures in preliminary rounds & 113 & 45 & 35 & 43 & 6 & 275 \\
\hline \# ventures in final rounds & 87 & 19 & 12 & 21 & 4 & 152 \\
\hline \# winners in preliminary rounds & 113 & 12 & 11 & 9.3 & 1 & 64 \\
\hline \# winners in final rounds & 87 & 4.5 & 4 & 3.7 & 1 & 25 \\
\hline Prize $\mid$ Prize $>0$ (thousand nominal \$) & 167 & 73 & 30 & 86 & 2 & 275 \\
\hline Days between rounds within competition & 88 & 23 & 17 & 31 & 0 & 127 \\
\hline \# judges in round-panel & 543 & 17 & 9 & 23 & 1 & 178 \\
\hline \multicolumn{7}{|c|}{ Panel 2: Ventures } \\
\hline & $\mathrm{N}$ & Mean & Median & S.d. & Min & $\operatorname{Max}$ \\
\hline \# unique ventures & 4,328 & & & & & \\
\hline Ventures in multiple competitions $(\# \mid>1)$ & 558 & 2.52 & 2 & 0.98 & 2 & 9 \\
\hline \# founders/team members at first competition & 2305 & 3.1 & 3 & 1.6 & 1 & 8 \\
\hline Venture age at first competition (years) & 2073 & 1.9 & 0.77 & 3 & 0 & 20 \\
\hline Incorporated at round & 4328 & 0.44 & & & & \\
\hline In hub state (CA, NY, MA) & 4328 & 0.35 & & & & \\
\hline Internet/software & 4328 & 0.52 & & & & \\
\hline Survival (Has >1 employee as of $8 / 2016$ ) & 4328 & 0.34 & & & & \\
\hline Has $\geq 10$ employees as of $8 / 2016$ & 4328 & 0.2 & & & & \\
\hline Raised external private investment before round & 7099 & 0.16 & & & & \\
\hline External private investment after round & 7099 & 0.24 & & & & \\
\hline Angel/VC series A investment before round & 7099 & 0.09 & & & & \\
\hline Angel/VC series A investment after round & 7099 & 0.15 & & & & \\
\hline Acquired/IPOd as of $9 / 2016$ & 4328 & 0.03 & & & & \\
\hline
\end{tabular}


Panel 3: Founders (Venture Leader - One Per Venture) $)^{\ddagger}$

\begin{tabular}{|c|c|c|c|c|c|c|}
\hline & $\mathrm{N}$ & Mean & Median & S.d. & Min & $\operatorname{Max}$ \\
\hline \# founders & 3228 & & & & & \\
\hline \# founders matched to LinkedIn profile & 2554 & & & & & \\
\hline Age (years) at event (college graduation year-22) & 1702 & 32.8 & 29 & 10.2 & 17 & 75 \\
\hline Female $^{ \pm}$ & 3,228 & 0.22 & & & & \\
\hline Male & 3,228 & 0.73 & & & & \\
\hline Number of total jobs & 2554 & 6.63 & 6 & 3.93 & 0 & 50 \\
\hline Number of jobs before round & 2547 & 4.41 & 4 & 2.66 & 0 & 10 \\
\hline Number of locations worked in & 2554 & 2.71 & 2 & 2.27 & 0 & 29 \\
\hline Is student at round & 2554 & 0.2 & & & & \\
\hline Graduated from top 20 college & 2554 & 0.27 & & & & \\
\hline Graduated from top 10 college & 2554 & 0.18 & & & & \\
\hline Graduated from Harvard, Stanford, MIT & 2554 & 0.1 & & & & \\
\hline Has MBA & 2554 & 0.48 & & & & \\
\hline Has MBA from top 10 business school & 2554 & 0.33 & & & & \\
\hline Has Master's degree & 2554 & 0.17 & & & & \\
\hline Has $\mathrm{PhD}$ & 2554 & 0.13 & & & & \\
\hline $\begin{array}{l}\text { Previous founder (founded different company before } \\
\text { competition) }\end{array}$ & 2554 & .02 & & & & \\
\hline Founder or CEO of subsequent venture after round & 2554 & 0.17 & & & & \\
\hline
\end{tabular}

Note: This table contains summary statistics about the competitions (panel 1), ventures (panel 2), and founders/team leaders (panel 3) used in analysis. Only the mean is provided for binary variables, other statistics provided for continuous variables. Data on ventures post-competition data is based on matches to CB Insights (752 unique matches), Crunchbase (638), AngelList $(1,528)$, and LinkedIn $(1,933) .{ }^{\ddagger}$ From LinkedIn profiles. Not all competitions retained founder data, so the number of venture leaders is less than the number of ventures. ${ }^{ \pm}$Gender coding by algorithm and manually; sexes do not sum to one because some names are both ambiguous and had no clear LinkedIn match. 


\section{Table 2: Effect of Winning on Subsequent External Financing}

\section{Panel 1}

Dependent variable: Financing after round

\begin{tabular}{|c|c|c|c|c|c|}
\hline & (1) & (2) & (3) & (4) & (5) \\
\hline Won Round & $\begin{array}{c}.088 * * * \\
(.018)\end{array}$ & $\begin{array}{l}.13 * * * \\
(.026)\end{array}$ & $\begin{array}{l}.079 * * \\
(.036)\end{array}$ & $\begin{array}{l}.17 * * * \\
(.015)\end{array}$ & $\begin{array}{l}.15^{* * * *} \\
(.019)\end{array}$ \\
\hline Decile rank & $\begin{array}{l}-.02 * * * \\
(.0027)\end{array}$ & & & & \\
\hline Decile rank winners & & $\begin{array}{c}-.011^{* * * *} \\
(.0044)\end{array}$ & $\begin{array}{l}-.0059 \\
(.0054)\end{array}$ & & \\
\hline Decile rank losers & & $\begin{array}{c}-.018 * * * \\
(.0025)\end{array}$ & $\begin{array}{c}-.013 * * * \\
(.0031)\end{array}$ & & \\
\hline Within-judge decile rank & & & & $\begin{array}{c}-.006 * * * \\
(.0011)\end{array}$ & \\
\hline Z-score winners & & & & & $\begin{array}{l}.0074 \\
(.024)\end{array}$ \\
\hline Z-score losers & & & & & $\begin{array}{c}.031 * * * \\
(.011)\end{array}$ \\
\hline Prize $(10,000 \$)$ & $\begin{array}{c}.0089 * * * \\
(.0023)\end{array}$ & $\begin{array}{c}.0085^{* * *} \\
(.0024)\end{array}$ & $\begin{array}{c}.0085^{* * *} \\
(.0029)\end{array}$ & $\begin{array}{l}.011 * * * \\
(.0034)\end{array}$ & $\begin{array}{l}.012^{* *} \\
(.0055)\end{array}$ \\
\hline Venture controls & $\mathrm{N}$ & $\mathrm{N}$ & $\mathrm{Y}$ & $\mathrm{N}$ & $\mathrm{N}$ \\
\hline Comp.-round-panel f.e. & $\mathrm{Y}$ & $\mathrm{Y}$ & $\mathrm{Y}$ & $\mathrm{Y}$ & $\mathrm{Y}$ \\
\hline Judge \& year f.e. & $\mathrm{N}$ & $\mathrm{N}$ & $\mathrm{N}$ & $\mathrm{Y}$ & $\mathrm{N}$ \\
\hline $\mathrm{N}$ & 6023 & 6023 & 3487 & 26663 & 3973 \\
\hline$R^{2}$ & .16 & .16 & .4 & .4 & .19 \\
\hline
\end{tabular}

Note: This panel shows regression estimates of the effect of winning, rank, and cash prize on whether the venture raised external financing after the competition using variants of Equation 1. The level of observation is a venture in a round (or panel, if the competitions divides rounds into discrete judging panels). Decile rank is the overall decile rank in the round, while decile rank winners (losers) is the decile rank within the round's winners (losers). A smaller rank is better (one is best decile, 10 is worst decile). Venture controls include whether the company received investment before the round, whether any of the venture's judges or those judges' firms ever invested in the venture, 17 sector indicator variables, company age, and whether the founder is a student. Competition fixed effects control for the date. Column 4 uses judge fixed effects, and the level of observation is judge-venture-round. Column 5 uses z-scores instead of ranks, and is restricted to the subsample of competitions that use scores before force-ranking participants. Errors clustered by competition-round-panel except in column 4 , where they are clustered by judge. *** indicates p-value<.01. 
Dependent variable: Financing after round

\begin{tabular}{|c|c|c|c|c|c|c|c|}
\hline & \multirow[b]{4}{*}{$(1)$} & \multirow[b]{4}{*}{ (2) } & \multirow[b]{4}{*}{ (3) } & \multicolumn{4}{|c|}{ Bandwidth around cutoff } \\
\hline & & & & \multirow[b]{3}{*}{ (4) } & \multirow{3}{*}{$\begin{array}{l}\text { ture } \\
\begin{array}{c}\text { No prize } \\
\text { winners }\end{array} \\
(5) \\
\end{array}$} & \multirow[b]{3}{*}{ (6) } & entures \\
\hline & & & & & & & $\begin{array}{l}\text { No prize } \\
\text { winners }\end{array}$ \\
\hline & & & & & & & (7) \\
\hline Won Round & $\begin{array}{l}.13 * * * \\
(.017)\end{array}$ & $\begin{array}{l}.13 * * * \\
(.019)\end{array}$ & $\begin{array}{l}.17 * * * \\
(.019)\end{array}$ & $\begin{array}{l}.16^{* * * *} \\
(.046)\end{array}$ & $\begin{array}{l}.11 * \\
(.064)\end{array}$ & $\begin{array}{l}.14 * * * \\
(.029)\end{array}$ & $\begin{array}{l}.086 * * \\
(.037)\end{array}$ \\
\hline Centered rank & $\begin{array}{l}.0018^{* * * *} \\
(.00032)\end{array}$ & $\begin{array}{l}.0018^{* * *} \\
(.00056)\end{array}$ & & & & & \\
\hline Centered rank ${ }^{2}$ & & $\begin{array}{l}-2.9 \mathrm{e}-07 \\
(3.9 \mathrm{e}-06)\end{array}$ & & & & & \\
\hline Centered rank winners & & & $\begin{array}{c}-.0066 * * * \\
(.0019)\end{array}$ & & & & \\
\hline Centered rank losers & & & $\begin{array}{l}.0023 * * * \\
(.00042)\end{array}$ & & & & \\
\hline Prize $(10,000 \$)$ & $\begin{array}{c}.0095 * * * \\
(.0024)\end{array}$ & $\begin{array}{c}.0095 * * * \\
(.0024)\end{array}$ & $\begin{array}{c}.0088^{* * *} \\
(.0024)\end{array}$ & $\begin{array}{c}.0037 \\
(.0095)\end{array}$ & & $\begin{array}{c}.007 \\
(.0062)\end{array}$ & \\
\hline Comp.-round-panel f.e. & $\mathrm{Y}$ & $\mathrm{Y}$ & $\mathrm{Y}$ & $\mathrm{Y}$ & $\mathrm{Y}$ & $\mathrm{Y}$ & $\mathrm{Y}$ \\
\hline $\mathrm{N}$ & 6023 & 6023 & 6023 & 971 & 781 & 1712 & 1404 \\
\hline$R^{2}$ & .16 & .16 & .16 & .52 & 6 & .35 & .37 \\
\hline
\end{tabular}

Note: This panel shows regression estimates of the effect of winning, rank, and cash prize on whether the venture raised external financing after the competition using variants of Equation 1. The level of observation is a venture in a round (or panel, if the competitions divides rounds into discrete judging panels). Centered rank is the venture's rank in the round centered around the cutoff for winning, such that a rank of 1 is the lowest-ranked winner, and -1 is the highest ranked loser. If there are three winners, the highest-ranked winner will have centered rank of 3 . If there are 20 losers, the lowest-ranked loser will have centered rank of -20 . Columns 4 and 5 restrict the sample to ranks immediately around the cutoff. Columns 4-5 use only one venture on either side of the cutoff, and columns 6-7 use two ventures on either side of the cutoff. Cash prize winners are excluded in columns 5 and 7. Competition fixed effects control for the date. Errors clustered by competition-round-panel. *** indicates p-value<.01. 
Table 3: Effect of Award and Round on Subsequent External Financing

Dependent variable: Financing after round

Sample:

$\frac{\text { All }}{} \frac{\text { Final rounds }}{\begin{array}{l}\text { no prize } \\ \text { winners }\end{array}}$

\begin{tabular}{c} 
Preliminary rounds \\
\hline $\begin{array}{r}\text { no final } \\
\text { winners }\end{array}$ \\
\hline
\end{tabular}

(1)

(2)

(3)

(4)

(5)

(6)

\begin{tabular}{|c|c|c|c|c|c|c|}
\hline \multirow[t]{2}{*}{ Won prelim round } & $.081 * * *$ & & & $.14 * * *$ & $.086 * * *$ & $.085 * *$ \\
\hline & $(.027)$ & & & $(.03)$ & $(.03)$ & $(.034)$ \\
\hline \multirow[t]{2}{*}{ Won final round } & $.2 * * *$ & $.12 * *$ & $.17 *$ & & $.2 * * *$ & \\
\hline & $(.033)$ & $(.05)$ & $(.085)$ & & $(.044)$ & \\
\hline \multirow[t]{2}{*}{ Decile rank winners } & $-.0096^{* *}$ & -.00047 & -.01 & $-.015 * * *$ & $-.012 * *$ & $-.011 *$ \\
\hline & $(.0039)$ & $(.0076)$ & $(.012)$ & $(.0052)$ & $(.0049)$ & $(.0058)$ \\
\hline \multirow[t]{2}{*}{ Decile rank losers } & $-.018 * * *$ & $-.019 * * *$ & $-.019 * * *$ & $-.018 * * *$ & $-.017 * * *$ & $-.017 * * *$ \\
\hline & $(.0025)$ & $(.004)$ & $(.0041)$ & $(.0031)$ & $(.0031)$ & $(.0031)$ \\
\hline \multirow[t]{2}{*}{ Prize (dummy) } & .00079 & & & & & \\
\hline & $(.032)$ & & & & & \\
\hline \multirow[t]{2}{*}{ Prize $(10,000 \$)$} & & .0052 & & $.012 * * *$ & .0032 & \\
\hline & & $(.0033)$ & & $(.0032)$ & $(.0037)$ & \\
\hline Comp.-round-panel f.e. & $\mathrm{Y}$ & $\mathrm{Y}$ & $\mathrm{Y}$ & $\mathrm{Y}$ & $\mathrm{Y}$ & $\mathrm{Y}$ \\
\hline $\mathrm{N}$ & 6023 & 1617 & 1286 & 4406 & 4406 & 4148 \\
\hline$R^{2}$ & .17 & .17 & .12 & .16 & .17 & .14 \\
\hline
\end{tabular}

Note: This panel shows regression estimates of the effect of winning, rank, and cash prize on whether the venture raised external financing after the competition using variants of Equation 1. The level of observation is a venture in a round (or panel, if the competitions divides rounds into discrete judging panels). Decile rank is the overall decile rank in the round, while decile rank winners (losers) is the decile rank within the round's winners (losers). A smaller rank is better (one is best decile, 10 is worst decile). Column 2 restricts the sample to final rounds, and column 3 to ventures in final rounds that did not win a cash prize. Columns 4-6 restrict the sample to preliminary rounds. Columns 7 further restrict the sample to ventures in preliminary rounds that did not ultimately win a prize. Competition fixed effects control for the date. Errors clustered by competition-round-panel. *** indicates p-value<.01. 
Table 4: Effect of Rank and Winning on Additional Outcomes

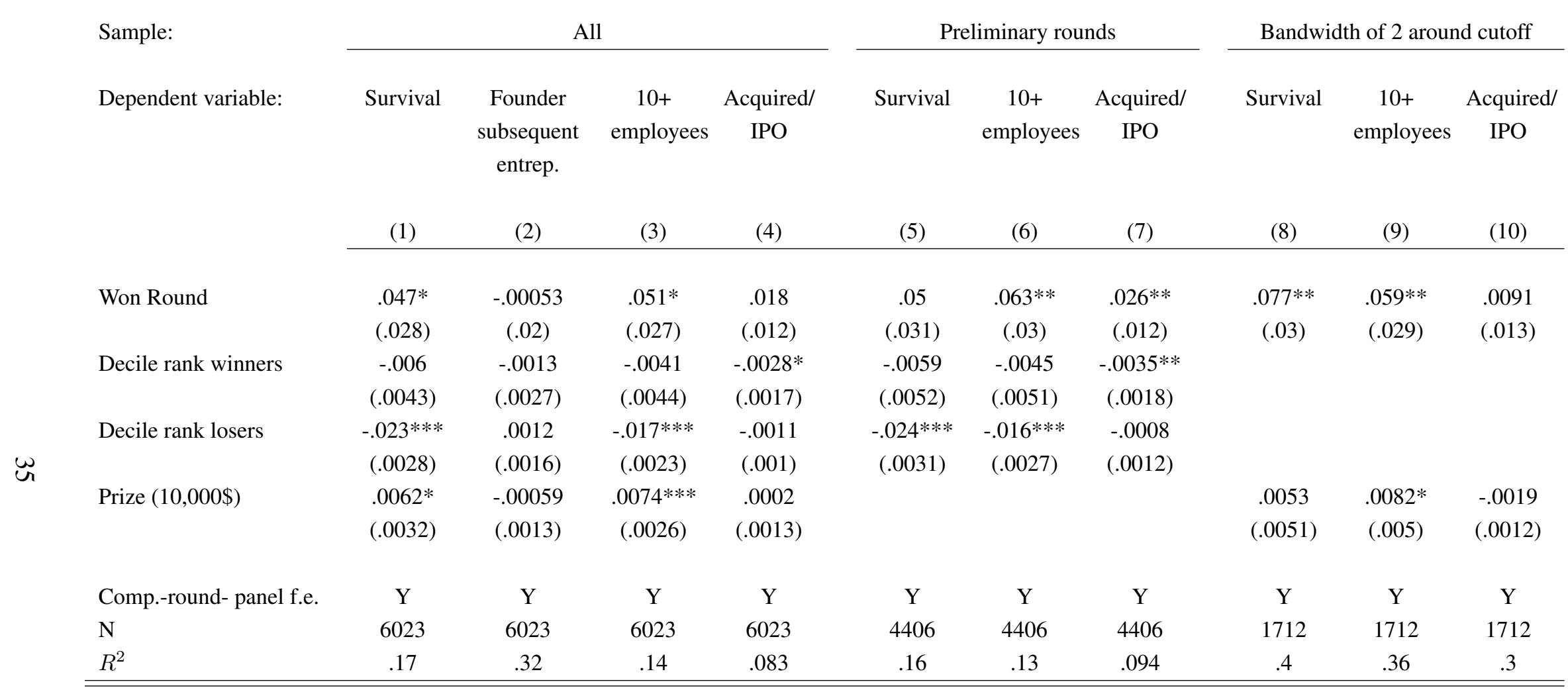

Note: This table shows regression estimates of Equation 1. Survival is one if the venture had $\geq 1$ employee besides the founder on LinkedIn as of 8/2016. 10+ employees is defined analogously. Acquired/IPO indicates that the venture was acquired by another company or went public. In columns 1-4, the whole sample is used. In column 2, the dependent variable is one for founders that subsequently founded or were the CEO of another company. This could reflect unidentified name changes, but if not, it is a measure of serial entrepreneurship. In columns 5-7, only preliminary rounds are included. In columns 8-10, the sample is restricted to a bandwidth of 2 ventures on either side of the cutoff for winning. The level of observation is a venture-round. Some rounds divide ventures into panels. Rank is defined as in Table 3 . Competition fixed effects control for the date. Errors clustered by competition-round-panel. *** indicates p-value<.01. 


\section{Table 5: Effect of Criteria Rank on Venture Outcomes}

\begin{tabular}{|c|c|c|c|c|c|c|}
\hline \multirow[t]{2}{*}{ Dependent variable: } & \multicolumn{2}{|c|}{ Financing after round } & \multicolumn{2}{|c|}{ 10+ Employees } & \multicolumn{2}{|c|}{ Acquired/IPO } \\
\hline & (1) & (2) & (3) & (4) & (5) & (6) \\
\hline \multicolumn{7}{|l|}{ Decile rank in round: } \\
\hline Team & $\begin{array}{c}-.021 * * * \\
(.0057)\end{array}$ & $\begin{array}{c}-.023 * * * \\
(.0053)\end{array}$ & $\begin{array}{l}-.0091 \\
(.0063)\end{array}$ & $\begin{array}{c}-.017 * * * \\
(.0049)\end{array}$ & $\begin{array}{l}.00069 \\
(.0026)\end{array}$ & $\begin{array}{l}-.0012 \\
(.0024)\end{array}$ \\
\hline Financials & $\begin{array}{l}-.014 * * \\
(.0067)\end{array}$ & $\begin{array}{l}-.0079 \\
(.005)\end{array}$ & $\begin{array}{c}-.036 * * * \\
(.0083)\end{array}$ & $\begin{array}{c}-.026 * * * \\
(.0057)\end{array}$ & $\begin{array}{c}.0034 \\
(.0031)\end{array}$ & $\begin{array}{c}.0023 \\
(.0027)\end{array}$ \\
\hline Business Model & $\begin{array}{l}.0032 \\
(.016)\end{array}$ & $\begin{array}{c}.002 \\
(.011)\end{array}$ & $\begin{array}{l}.0024 \\
(.014)\end{array}$ & $\begin{array}{l}.0035 \\
(.011)\end{array}$ & $\begin{array}{c}.0046 \\
(.0074)\end{array}$ & $\begin{array}{l}-.0059 \\
(.0074)\end{array}$ \\
\hline Market & $\begin{array}{c}.01 \\
(.015)\end{array}$ & $\begin{array}{l}-.0091 \\
(.011)\end{array}$ & $\begin{array}{l}.0075 \\
(.013)\end{array}$ & $\begin{array}{l}-.011 \\
(.011)\end{array}$ & $\begin{array}{l}-.00047 \\
(.0072)\end{array}$ & $\begin{array}{c}.0039 \\
(.0074)\end{array}$ \\
\hline Tech./Product & $\begin{array}{c}.0098 \\
(.0078)\end{array}$ & $\begin{array}{c}.0031 \\
(.0054)\end{array}$ & $\begin{array}{l}-.0015 \\
(.0069)\end{array}$ & $\begin{array}{l}-.0081 \\
(.0054)\end{array}$ & $\begin{array}{c}-.0062 * * \\
(.0024)\end{array}$ & $\begin{array}{c}-.0056^{* *} \\
(.0024)\end{array}$ \\
\hline Presentation & $\begin{array}{l}-.015 * * \\
(.0059)\end{array}$ & $\begin{array}{c}-.0098 * * \\
(.0043)\end{array}$ & $\begin{array}{c}.0074 \\
(.0071)\end{array}$ & $\begin{array}{c}.008 \\
(.0052)\end{array}$ & $\begin{array}{l}-.0032 \\
(.0024)\end{array}$ & $\begin{array}{l}-.0013 \\
(.0022)\end{array}$ \\
\hline Won Round & $\begin{array}{l}.14 * * * \\
(.024)\end{array}$ & $\begin{array}{l}.2 * * * \\
(.013)\end{array}$ & $\begin{array}{l}.1 * * * \\
(.032)\end{array}$ & $\begin{array}{l}.17 * * * \\
(.015)\end{array}$ & $\begin{array}{c}.011 \\
(.013)\end{array}$ & $\begin{array}{c}.023 * * * \\
(.0068)\end{array}$ \\
\hline Judge/judge co invested & $\begin{array}{c}.47 * * * \\
(.11)\end{array}$ & $\begin{array}{l}.56^{* * * *} \\
(.027)\end{array}$ & & & & \\
\hline Comp,-round-panel f.e. & $\mathrm{Y}$ & $\mathrm{N}$ & $\mathrm{Y}$ & $\mathrm{N}$ & $\mathrm{Y}$ & $\mathrm{N}$ \\
\hline Judge f.e. & $\mathrm{N}$ & $\mathrm{Y}$ & $\mathrm{N}$ & $\mathrm{Y}$ & $\mathrm{N}$ & $\mathrm{Y}$ \\
\hline $\mathrm{N}$ & 1926 & 8794 & 1926 & 8794 & 1926 & 7043 \\
\hline$R^{2}$ & .15 & .14 & .13 & .12 & .065 & .066 \\
\hline
\end{tabular}

Note: This table contains regression estimates of the relationship between criteria-specific ranks and venture outcomes. The level of observation is a venture in a round (or panel, if the competitions divides rounds into discrete judging panels). The criteria ranks are averaged to produce the overall ranks used in other tables. A smaller decile rank is better (one is best decile, 10 is worst decile). Financing after round is an indicator for the venture raising private external investment after the round. 10+ employees is one if the venture had $\geq 10$ employees besides the founder on LinkedIn as of 8/2016. Competition fixed effects control for the date. Errors clustered by competition-round-panel or judge, depending on fixed effects. $* * *$ indicates p-value $<.01$. 
Table 6: Robustness Tests of Effect of Winning

Panel 1

Dependent variable: Financing after round

Logit Feedback $\begin{gathered}\text { No } \\ \text { feedback }\end{gathered}$

\begin{tabular}{|c|c|c|c|c|c|c|}
\hline & & & & Logit & Feedback & $\begin{array}{c}\text { No } \\
\text { feedback }\end{array}$ \\
\hline & (1) & (2) & (3) & $(4)$ & (5) & (6) \\
\hline Won Round & $\begin{array}{c}.13 * * * \\
(.03)\end{array}$ & $\begin{array}{l}.13 * * * \\
(.026)\end{array}$ & $\begin{array}{l}.13 * * * \\
(.027)\end{array}$ & $\begin{array}{c}.71 * * * \\
(.14)\end{array}$ & $\begin{array}{l}.13 * * * \\
(.034)\end{array}$ & $\begin{array}{c}.17 * * * \\
(.04)\end{array}$ \\
\hline Decile rank winners & $\begin{array}{l}-.011 * * \\
(.0043)\end{array}$ & $\begin{array}{c}-.012 * * * \\
(.0043)\end{array}$ & $\begin{array}{c}-.012 * * \\
(.0047)\end{array}$ & $\begin{array}{c}-.069 * * * \\
(.021)\end{array}$ & $\begin{array}{l}-.0091 \\
(.0061)\end{array}$ & $\begin{array}{c}-.017 * * * \\
(.0063)\end{array}$ \\
\hline Decile rank losers & $\begin{array}{c}-.018 * * * \\
(.0027)\end{array}$ & $\begin{array}{c}-.018 * * * \\
(.0025)\end{array}$ & $\begin{array}{c}-.017 * * * \\
(.0026)\end{array}$ & $\begin{array}{c}-.13 * * * \\
(.017)\end{array}$ & $\begin{array}{c}-.011 * * * \\
(.0033)\end{array}$ & $\begin{array}{c}-.025 * * * \\
(.0033)\end{array}$ \\
\hline Prize $(10,000 \$)$ & $\begin{array}{c}.0085^{* * *} \\
(.0023)\end{array}$ & $\begin{array}{c}.0088^{* * *} * \\
(.0023)\end{array}$ & $\begin{array}{l}.0067^{*} \\
(.0039)\end{array}$ & $\begin{array}{c}.036^{* * * *} \\
(.011)\end{array}$ & $\begin{array}{l}.011 * * \\
(.0055)\end{array}$ & $\begin{array}{c}.0068 * * \\
(.0027)\end{array}$ \\
\hline Comp.-round-panel f.e. & $\mathrm{Y}$ & $\mathrm{Y}$ & $\mathrm{Y}$ & $\mathrm{Y}$ & $\mathrm{Y}$ & $\mathrm{Y}$ \\
\hline $\mathrm{N}$ & 6023 & 5925 & 4920 & 5484 & 3422 & 2601 \\
\hline$R^{2}$ & .16 & .16 & .17 & .12 & .2 & .13 \\
\hline
\end{tabular}

Note: This panel shows regression estimates of the effect of winning, rank, and cash prize on whether the venture raised external financing after the competition using variants of Equation 1. The level of observation is a venture in a round (or panel, if the competitions divides rounds into discrete judging panels). Decile rank is the overall decile rank in the round, while decile rank winners (losers) is the decile rank within the round's winners (losers). A smaller rank is better (one is best decile, 10 is worst decile). Column 1 clusters errors by competition. Column 2 omits ventures in which a judge or judge's firm invested. Column 3 restricts observations to a venture's first competition. Column 4 uses a logit model instead of OLS. Column 5 restricts the sample to competitions that gave participants feedback (informed them of their rank in the round), while column 6 restricts the sample to competitions that did not provide feedback. Competition fixed effects control for the date. Errors clustered by competition-round-panel except in columns 1 and 4 , where they are clustered by competition and judge, respectively. $* * *$ indicates p-value<.01. 


\section{Panel 2}

Dependent variable: Financing after round

\begin{tabular}{|c|c|c|c|c|c|c|c|c|c|}
\hline \multirow[t]{3}{*}{ Sample: } & \multicolumn{2}{|c|}{ University comps } & \multirow{2}{*}{$\begin{array}{c}\text { HBS NVC } \\
\text { omitted }\end{array}$} & \multirow{2}{*}{$\begin{array}{c}\text { AIC } \\
\text { omitted }\end{array}$} & \multirow{2}{*}{$\begin{array}{l}\text { No small } \\
\text { comps }\end{array}$} & \multicolumn{2}{|c|}{ Ventures } & \multicolumn{2}{|c|}{ Founders } \\
\hline & Omitted & Only & & & & $\begin{array}{c}\text { in } \mathrm{VC} \text { hub } \\
\text { states }\end{array}$ & incorp. & $\begin{array}{c}\text { with } \\
\text { MBAs }\end{array}$ & students \\
\hline & (1) & (2) & (3) & (4) & (5) & (6) & (7) & (8) & (9) \\
\hline Won Round & $.12 * * *$ & $.15^{* * *}$ & $.13 * * *$ & $.13 * * *$ & $.15^{* * *}$ & $.13 * * *$ & $.14 * * *$ & $.12 * *$ & $.13 * *$ \\
\hline & $(.039)$ & $(.037)$ & $(.029)$ & $(.029)$ & $(.028)$ & $(.049)$ & $(.038)$ & $(.053)$ & $(.056)$ \\
\hline Decile rank winners & $-.012 * *$ & -.01 & $-.013 * * *$ & $-.01 * *$ & $-.013 * * *$ & -.011 & $-.015 * *$ & -.0056 & -.014 \\
\hline & $(.0057)$ & $(.008)$ & $(.0046)$ & $(.005)$ & $(.0047)$ & $(.0082)$ & $(.0059)$ & $(.011)$ & $(.012)$ \\
\hline Decile rank losers & $-.022 * * *$ & $-.011 * *$ & $-.021 * * *$ & $-.015 * * *$ & $-.019 * * *$ & $-.011 * *$ & $-.025 * * *$ & -.0091 & $-.024 * * *$ \\
\hline & $(.0029)$ & $(.0043)$ & $(.0026)$ & $(.0029)$ & $(.0026)$ & $(.0049)$ & $(.0034)$ & $(.0057)$ & $(.006)$ \\
\hline Prize $(10,000 \$)$ & $.0081 * * *$ & $.01^{*}$ & $.0078 * * *$ & $.01 * * *$ & $.0082 * * *$ & .0074 & $.0074 * * *$ & $.017 *$ & .012 \\
\hline & $(.0026)$ & $(.0057)$ & $(.0024)$ & $(.0039)$ & $(.0025)$ & $(.012)$ & $(.0027)$ & $(.0094)$ & (.0086) \\
\hline Comp--round-panel f.e. & $\mathrm{Y}$ & $\mathrm{Y}$ & $\mathrm{Y}$ & $\mathrm{Y}$ & $\mathrm{Y}$ & $\mathrm{Y}$ & $\mathrm{Y}$ & $\mathrm{Y}$ & Y \\
\hline $\mathrm{N}$ & 3616 & 2407 & 5235 & 4460 & 5442 & 1968 & 3288 & 1637 & 1183 \\
\hline$R^{2}$ & .11 & .24 & .15 & .19 & .17 & .28 & .18 & .34 & .33 \\
\hline
\end{tabular}

Note: This table shows regression estimates like those in Panel 1. The sample is divided by competition, venture, or founder characteristics. Column 1 excludes competitions organized by universities, while column 2 includes only these competitions. Columns 3 and 4 omit the two largest competitions in the data, the HBS New Venture Competition and the Arizona Innovation Challenge, respectively. Column 5 omits competitions where there are less than 30 participants. Competition fixed effects control for the date. Errors clustered by competition-round-panel. *** indicates p-value<.01. 
Dependent variable: Financing after round

$C: \quad \begin{array}{ccc}\text { Founder BA from } & \text { Founder founded } \\ \text { top } 10 \text { college } & \text { previous company } & \begin{array}{c}\text { Internet/software-based } \\ \text { venture }\end{array}\end{array}$

(1)

(2)

(3)

\begin{tabular}{|c|c|c|c|}
\hline Won Round & $\begin{array}{l}.13 * * * \\
(.028)\end{array}$ & $\begin{array}{c}.097 * * * \\
(.035)\end{array}$ & $\begin{array}{l}.041 \\
(.031)\end{array}$ \\
\hline Won Round $\cdot C$ & $\begin{array}{l}-.0027 \\
(.081)\end{array}$ & $\begin{array}{c}.049 \\
(.058)\end{array}$ & $\begin{array}{l}.21 * * * \\
(.056)\end{array}$ \\
\hline Decile rank winners & $\begin{array}{l}-.011 * * \\
(.0046)\end{array}$ & $\begin{array}{l}-.0057 \\
(.0059)\end{array}$ & $\begin{array}{c}-.0089 * \\
(.0048)\end{array}$ \\
\hline Decile rank winners. $C$ & $\begin{array}{l}-.0039 \\
(.013)\end{array}$ & $\begin{array}{l}-.013 * \\
(.0077)\end{array}$ & $\begin{array}{l}-.0087 \\
(.0076)\end{array}$ \\
\hline Decile rank losers & $\begin{array}{c}-.018 * * * \\
(.0026)\end{array}$ & $\begin{array}{c}-.015 * * * \\
(.003)\end{array}$ & $\begin{array}{c}-.014 * * * \\
(.0024)\end{array}$ \\
\hline Decile rank losers. $C$ & $\begin{array}{c}.0068 \\
(.0083)\end{array}$ & $\begin{array}{l}-.0075 \\
(.0048)\end{array}$ & $\begin{array}{l}-.011 * * \\
(.0048)\end{array}$ \\
\hline Prize $(10,000 \$)$ & $\begin{array}{c}.0098 * * * \\
(.0024)\end{array}$ & $\begin{array}{l}.013 * * * \\
(.0029)\end{array}$ & $\begin{array}{c}.0042 \\
(.0036)\end{array}$ \\
\hline Prize $(10,000 \$) \cdot C$ & $\begin{array}{l}-.013 * * \\
(.0056)\end{array}$ & $\begin{array}{c}-.0084 * * \\
(.004)\end{array}$ & $\begin{array}{c}.0016 \\
(.0044)\end{array}$ \\
\hline$C$ & $\begin{array}{c}.076 \\
(.049)\end{array}$ & $\begin{array}{c}.14 * * * \\
(.03)\end{array}$ & $\begin{array}{l}.28 * * * \\
(.036)\end{array}$ \\
\hline Comp.-round- panel f.e. & $\mathrm{Y}$ & $\mathrm{Y}$ & $\mathrm{Y}$ \\
\hline $\mathrm{N}$ & 6023 & 6023 & 6023 \\
\hline$R^{2}$ & .17 & .18 & .24 \\
\hline
\end{tabular}

Note: This table shows regression estimates of heterogeneity in the effect of winning, rank, and cash prize on whether the venture raised external financing after the competition. The level of observation is a venture in a round (or panel, if the competitions divides rounds into discrete judging panels). The characteristic in the column header is interacted with all covariates except the competition fixed effects. Competition fixed effects control for the date. Errors clustered by competition-round-panel. $* * *$ indicates p-value $<.01$. 
Figure 1: Continuity of Venture Covariates
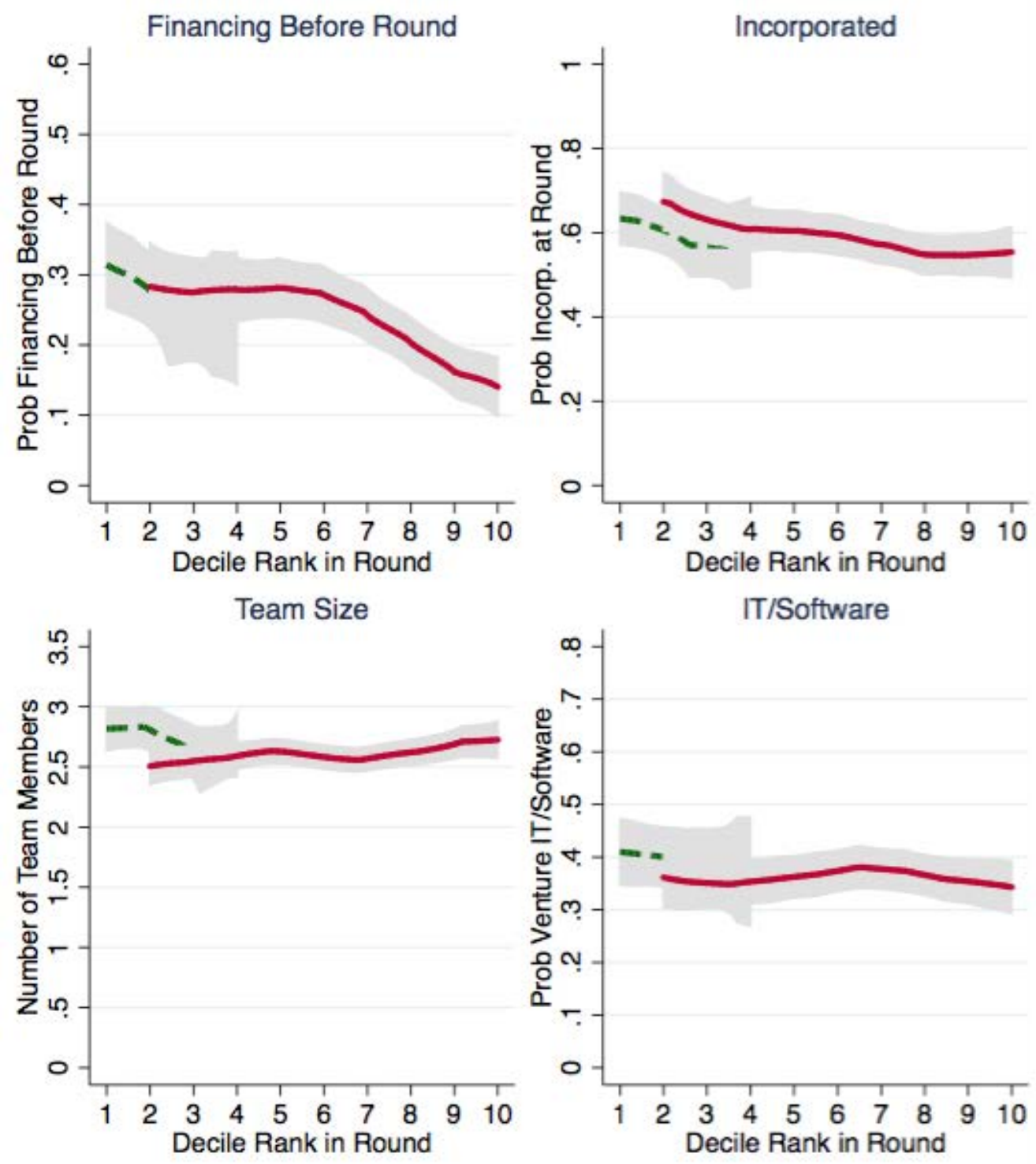

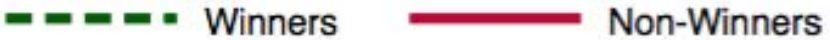

Note: This figure shows probabilities of venture-specific covariates observed at the time of the competition by percentile rank in the round (lower percentile rank is better). Final rounds are used. There are no losers in the top bin, and winners are truncated at the fifth decile. The lines overlap because the share of participants that win varies across rounds. Local polynomial with Stata's optimal bandwidth. 95\% CIs shown. 
Figure 2: Continuity of Founder Covariates
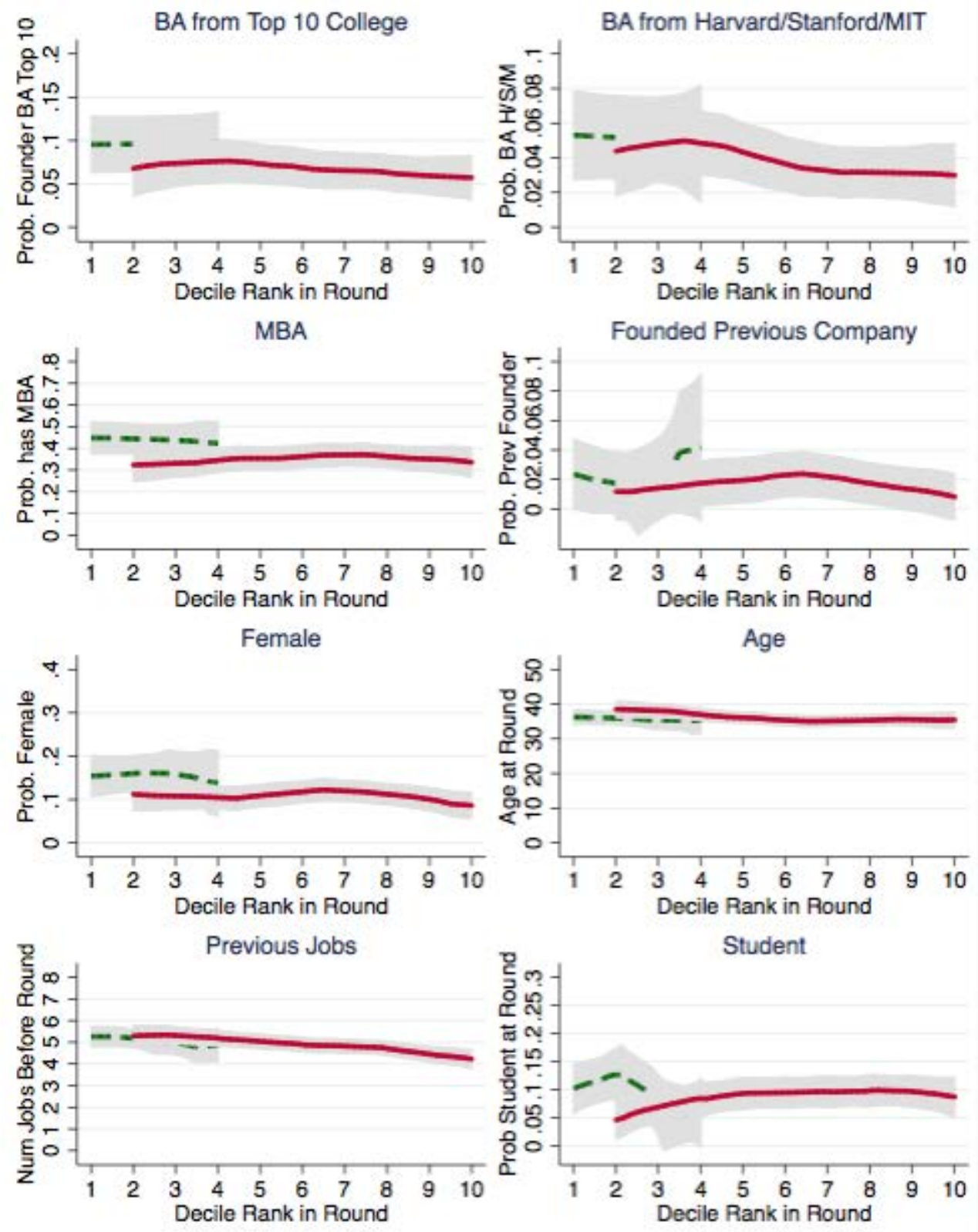

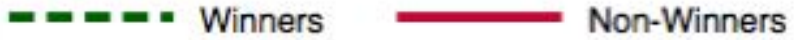

Note: This figure shows probabilities of founder-specific covariates observed at the time of the competition by percentile rank in the round (lower percentile rank is better). Final rounds are used. There are no losers in the top bin, and winners are truncated at the fifth decile. The lines overlap because the share of participants that win varies across rounds. Local polynomial with Stata's optimal bandwidth. 95\% CIs shown. 
Figure 3: Effect of winning with percentile rank
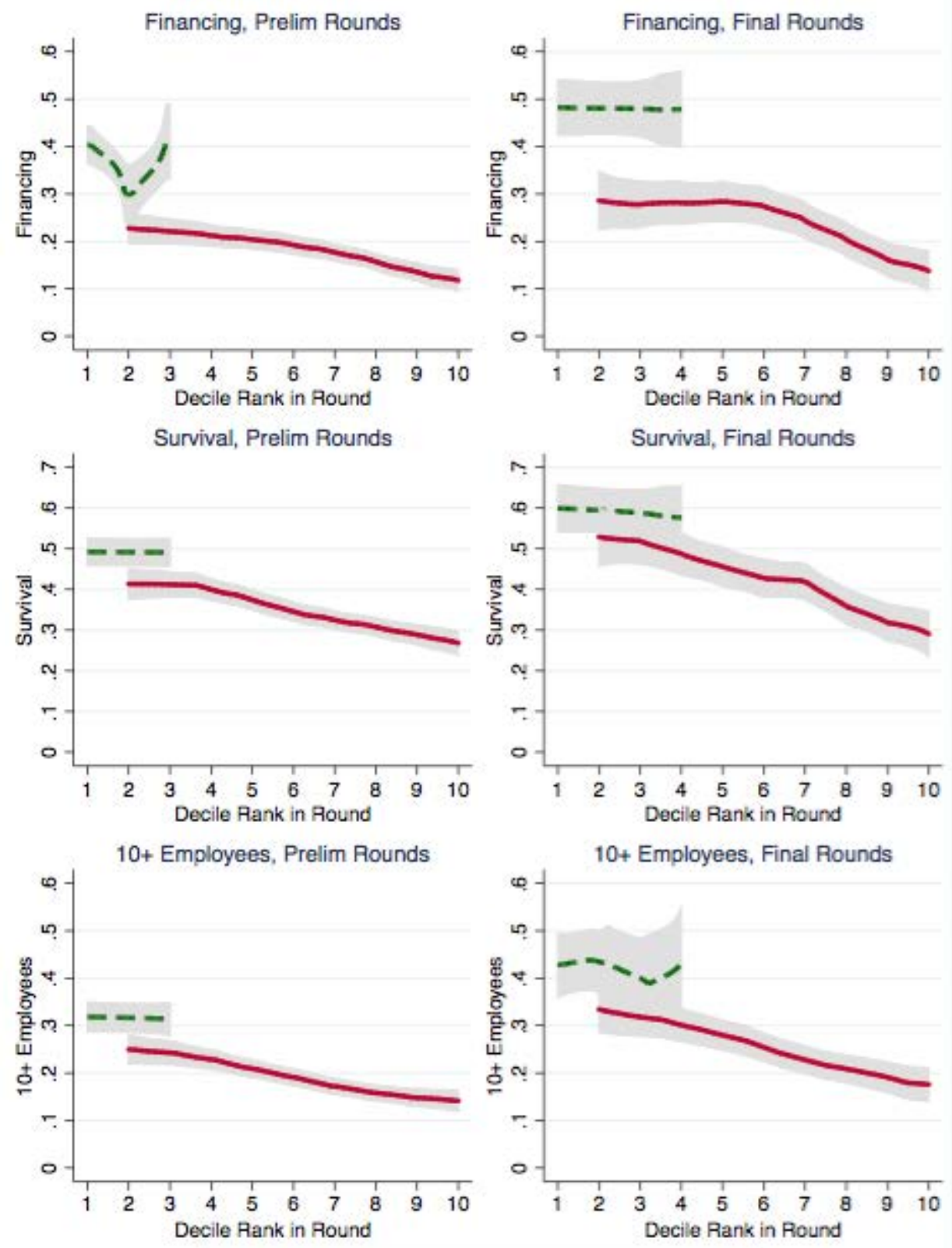

- - - - Winners

\section{Losers}

Note: This figure shows probabilities of subsequent financing (top), survival (middle), and having 10+ employees (bottom) by percentile rank in the round (lower percentile rank is better). There are no losers in the top bin, and winners are truncated at the fourth and fifth decile for preliminary and final rounds, respectively. The lines overlap because the share of participants that win varies across rounds. Local polynomial with Stata's optimal bandwidth. $95 \%$ CIs shown. 
Figure 4: Effect of winning with centered rank around cutoff
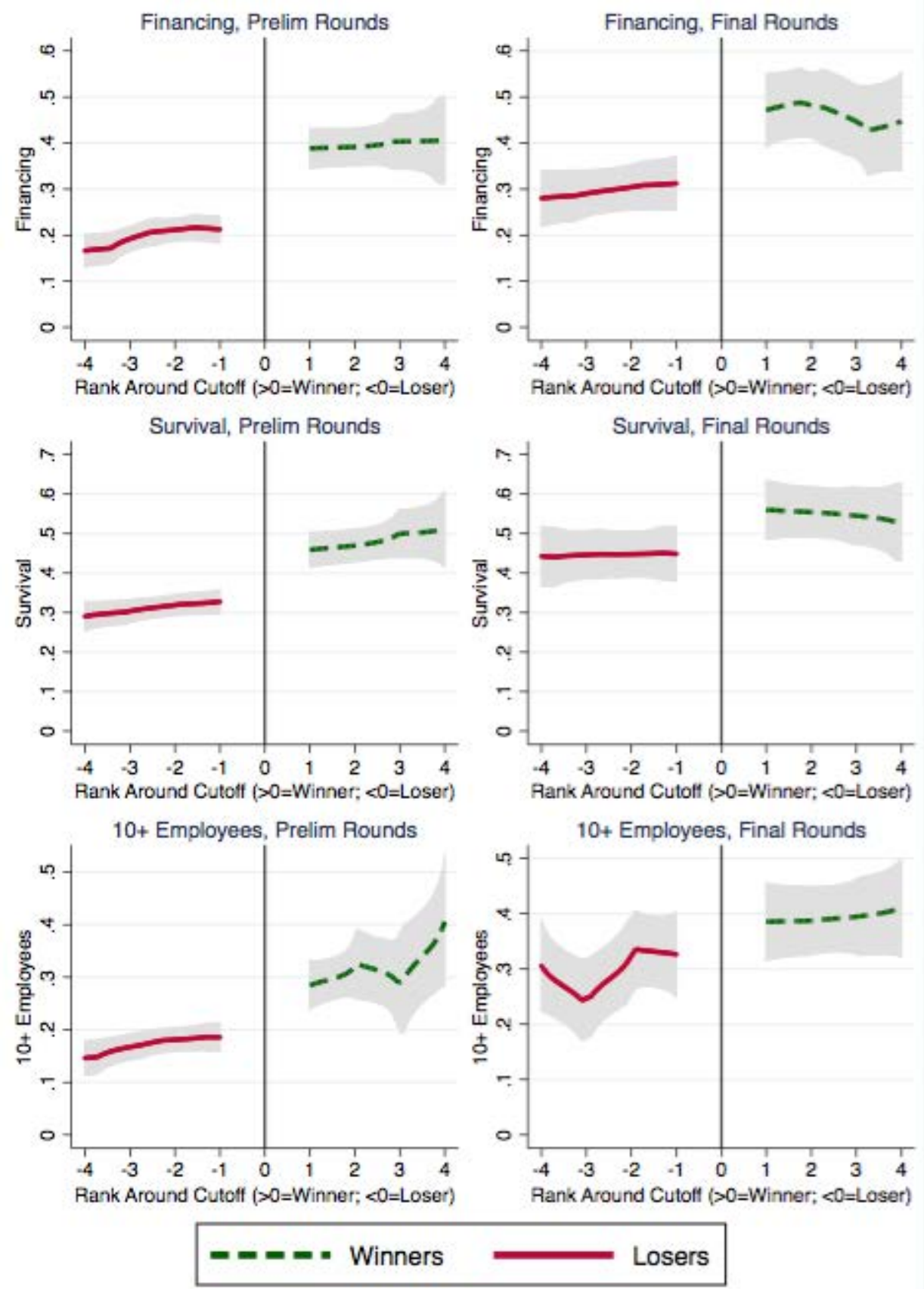

Note: This figure shows probabilities of subsequent financing (top), survival (middle), and having 10+ employees (bottom) by the venture's centered rank around the cutoff for winning. Centered rank improves from left to right. A rank of 1 indicates the lowest ranked ranked winner (the winner with the worst rank, which just barely won). A rank of -1 indicated the highest ranked loser (the loser which just barely lost). Local polynomial with Stata's optimal bandwidth. 95\% CIs shown. 


\section{Online Appendix to}

"Reducing Information Frictions in Venture Capital: The Role of New Venture Competitions"

Sabrina T. Howell 
Table A.1: Competitions

\begin{tabular}{|c|c|c|c|c|c|c|}
\hline \multirow[b]{2}{*}{ Competition Name } & \multicolumn{3}{|c|}{ Panel 1} & \multirow[b]{2}{*}{$\begin{array}{l}\text { \# unique } \\
\text { ventures }\end{array}$} & \multirow[b]{2}{*}{$\begin{array}{l}\text { \# unique } \\
\text { judges }\end{array}$} & \multirow[b]{2}{*}{$\begin{array}{l}\text { \# rounds } \\
\text { per comp }\end{array}$} \\
\hline & City & State & Years & & & \\
\hline $\begin{array}{l}\text { Arizona Innovation } \\
\text { Challenge Fall }\end{array}$ & Phoenix & $\mathrm{AZ}$ & $2012-2015$ & 489 & 90 & 2 \\
\hline $\begin{array}{l}\text { Arizona Innovation } \\
\text { Challenge Spring }\end{array}$ & Phoenix & $\mathrm{AZ}$ & $2012-2015$ & 610 & 87 & 2 \\
\hline Angel Capital Summit & Denver & $\mathrm{CO}$ & $2014-15$ & 195 & 55 & 1 \\
\hline $\begin{array}{l}\text { BRF Entrepreneur } \\
\text { Accelerator Program (EAP) }\end{array}$ & Shreveport & LA & 2014 & 22 & 4 & 1 \\
\hline $\begin{array}{l}\text { CU CleanTech New Venture } \\
\text { Challenge }\end{array}$ & Boulder & $\mathrm{CO}$ & $2012-13$ & 27 & 35 & 1 \\
\hline Clean Energy Challenge & Chicago & IL & 2013 & 50 & 55 & 2 \\
\hline Cleantech Open: California & $\begin{array}{l}\text { Redwood } \\
\text { City }\end{array}$ & CA & $2009-14$ & 231 & 163 & 2 \\
\hline $\begin{array}{l}\text { Cleantech Open: North } \\
\text { Central }\end{array}$ & Minneapolis & $\mathrm{MN}$ & $2010-13$ & 109 & 103 & 2 \\
\hline Cleantech Open: Northeast & Boston & MA & $2009-13$ & 233 & 137 & 2 \\
\hline $\begin{array}{l}\text { Cleantech Open: Pacific } \\
\text { Northwest }\end{array}$ & Portland & OR & $2009-13$ & 62 & 38 & 2 \\
\hline $\begin{array}{l}\text { Cleantech Open: Rocky } \\
\text { Mountain }\end{array}$ & Denver & $\mathrm{CO}$ & $2009-13$ & 133 & 61 & 2 \\
\hline $\begin{array}{l}\text { Cleantech Open: South } \\
\text { Central }\end{array}$ & Austin & $\mathrm{TX}$ & 2011-13 & 11 & 12 & 2 \\
\hline Cleantech Open: Southeast & Atlanta & GA & 2011-13 & 24 & 37 & 2 \\
\hline $\begin{array}{l}\text { Colorado Capital } \\
\text { Conference } 2013\end{array}$ & Denver & $\mathrm{CO}$ & 2013 & 52 & 23 & 2 \\
\hline $\begin{array}{l}\text { Colorado Digital Health } \\
\text { Challenge }\end{array}$ & Denver & $\mathrm{CO}$ & 2014 & 33 & 46 & 2 \\
\hline $\begin{array}{l}\text { DOE Cleantech Business } \\
\text { Plan Competition }\end{array}$ & Washington & D.C. & 2013 & 6 & 5 & 2 \\
\hline Energize 2013 & Snowbird & UT & 2013 & 22 & 12 & 1 \\
\hline $\begin{array}{l}\text { Energy Security Prize, EIA } \\
\text { Track }\end{array}$ & Washington & D.C. & 2013 & 16 & 18 & 2 \\
\hline $\begin{array}{l}\text { Harvard Business School } \\
\text { New Venture Competition }\end{array}$ & Boston & MA & 1999-2015 & 817 & 563 & $2^{\ddagger}$ \\
\hline
\end{tabular}




\section{Panel 2}

\begin{tabular}{|c|c|c|c|c|c|c|}
\hline Competition Name & City & State & Years & $\begin{array}{l}\text { \# unique } \\
\text { ventures }\end{array}$ & $\begin{array}{l}\text { \# unique } \\
\text { judges }\end{array}$ & $\begin{array}{l}\text { \# rounds } \\
\text { per comp. }\end{array}$ \\
\hline Illinois Clean Energy & Chicago & IL & 2013 & 26 & 9 & 1 \\
\hline \multicolumn{7}{|l|}{ Student Challenge } \\
\hline Imagine $\mathrm{H} 2 \mathrm{O}$ Infrastructure & San & $\mathrm{CA}$ & $2013-15$ & 160 & 31 & 3 \\
\hline Challenge & Francisco & & & & & \\
\hline Innosphere Admissions & Fort Collins & $\mathrm{CO}$ & $2013-15$ & 32 & 46 & 1 \\
\hline MIT Clean Energy Prize & Cambridge & MA & $2013-15$ & 156 & 80 & $2-3^{\lambda}$ \\
\hline Missouri Clean Energy & St. Louis & MO & 2013 & 14 & 9 & 1 \\
\hline \multicolumn{7}{|l|}{ Student Challenge } \\
\hline OEDIT Advanced & Denver & $\mathrm{CO}$ & 2015 & 36 & 7 & 1 \\
\hline \multicolumn{7}{|l|}{ Industries Accelerator } \\
\hline \multicolumn{7}{|l|}{ Energy and Natural } \\
\hline \multicolumn{7}{|l|}{ Resources } \\
\hline Ohio Clean Energy Student & Cleveland & $\mathrm{OH}$ & $2012-13$ & 12 & 8 & 1 \\
\hline \multicolumn{7}{|l|}{ Challenge } \\
\hline TransTech Energy & Morgantown & WV & 2012 & 20 & 25 & 1 \\
\hline \multicolumn{7}{|l|}{ Conference 2012} \\
\hline Massachusetts Clean & Boston & MA & $2012-15$ & 250 & 134 & 2 \\
\hline \multicolumn{7}{|l|}{ Energy Center Catalyst } \\
\hline \multicolumn{7}{|l|}{ Grant Program } \\
\hline Rice University Business & Houston & TX & 2004-2015 & 480 & 694 & $3^{\dagger}$ \\
\hline Plan Competition & & & & & & \\
\hline
\end{tabular}

Notes: This table lists the programs whose competitions are used in this paper. ${ }^{\ddagger}$ First round done in panels of 4-8 ventures and 5-15 judges per panel, varies somewhat year to year (note: there is small finals for top three teams, all of which win a cash prize. Do not have data for this final round) ${ }^{\dagger}$ First round, challenge round, and semifinal rounds all "tracked" into panels (what RBPC calls "flights"). First round tracked by sector, then firms randomized across panels. non-winners of first round go on to "Challenge" round. There is also pre-competition business plan stage. ${ }^{\lambda}$ Depends on year. 
Table A.2: University and MBA Rankings

\begin{tabular}{ll|ll}
\hline \multicolumn{2}{c|}{ Top Twenty U.S. Universities } & \multicolumn{2}{|c}{ Top Ten MBA Programs } \\
Rank & Name & Rank & Name \\
1 & PRINCETON & 1 & HARVARD \\
2 & HARVARD & 2 & STANFORD \\
3 & YALE & 3 & CHICAGO \\
4 & COLUMBIA & 4 & UPENN \\
5 & STANFORD & 5 & MIT \\
6 & CHICAGO & 6 & NORTHWESTERN \\
7 & MIT & 7 & UC BERKELEY \\
8 & DUKE & 8 & DARTMOUTH \\
9 & UPENN & YALE \\
10 & CALTECH & & COLUMBIA \\
11 & JOHNS HOPKINS & & \\
12 & DARTMOUTH & & \\
13 & NORTHWESTERN & & \\
14 & BROWN & & \\
15 & CORNELL & \\
16 & VANDERBILT & & \\
17 & WASH ST LOUIS & & \\
\hline \hline
\end{tabular}

Note: This table describes the university rankings used in analysis. Source: US News \& World Report 2016 Rankings. 
Table A.3: Sector and Judge Data

\begin{tabular}{|c|c|c|c|c|}
\hline \multicolumn{3}{|c|}{ Panel 1: Sectors } & \multicolumn{2}{|l|}{ Panel 2: Judge Professions } \\
\hline & \multicolumn{2}{|l|}{ Sectors ${ }^{\ddagger}$} & \multicolumn{2}{|c|}{ \# unique judges } \\
\hline & Ventures & Judges & All & 2,514 \\
\hline Air/water/waste/agriculture & 146 & 31 & Venture Capital Investor & 676 \\
\hline Biotech & 182 & 64 & Elite $\mathrm{VC}^{\dagger}$ (by IRR/Multiple) & 21 \\
\hline Clean tech/renewable energy & 712 & 273 & Angel Investor* & 397 \\
\hline Defense/security & 64 & 66 & Mean (med) AngelList investments & $12.8(8)$ \\
\hline Education & 37 & 118 & Professor/Scientist & 44 \\
\hline Energy (fossil) & 61 & 373 & Business Development/Sales & 83 \\
\hline Fintech/financial & 53 & 522 & Corporate Executive & 498 \\
\hline Food/beverage & 88 & 24 & Founder/Entrepreneur & 240 \\
\hline Health (ex biotech) & 270 & 291 & Lawyer/Consultant/Accountant & 369 \\
\hline IT/web & 1,404 & 586 & Non-Profit/Foundation/Government & 164 \\
\hline Manuf./materials/electronics & 323 & 96 & Other & 193 \\
\hline Media/ads/entertainment & 57 & 157 & & \\
\hline Real estate & 61 & 82 & \# judge-venture pairs in which judge & \\
\hline Retail/consumer goods & 139 & 159 & personally invested in venture & 3 \\
\hline Social enterprise & 42 & 42 & \# judge-venture pairs in which & \\
\hline \multirow[t]{3}{*}{ Transportation } & 136 & 51 & judge's firm invested in venture & 95 \\
\hline & & & Total \# judge-venture score pairs & 47,066 \\
\hline & & & \# judge-venture pairs in same sector & 8,139 \\
\hline
\end{tabular}

Note: This table lists the number of ventures by technology type and the number of judges by profession. ${ }^{\dagger}$ Preqin top $20 \mathrm{VC}$ firm by either IRR or Multiple, as of 2016. * Identifies as angel investor in competition data, or has AngelList profile and at least one investment (160 judges). ${ }^{\ddagger}$ Venture sectors from competition data; each venture assigned to one sector. Judge sectors based on LinkedIn profile or firm webpage; judges may have expertise in multiple sectors. 
Table A.4: Company \& Competition States

\begin{tabular}{|c|c|c|c|c|c|}
\hline State & $\begin{array}{c}\# \\
\text { competitions } \\
\text { in state }\end{array}$ & $\begin{array}{c}\text { \# ventures } \\
\text { located in state }\end{array}$ & State & $\begin{array}{c}\# \\
\text { competitions } \\
\text { in state }\end{array}$ & $\begin{array}{c}\text { \# ventures } \\
\text { located in state }\end{array}$ \\
\hline Arizona & 8 & 665 & Idaho & & 9 \\
\hline California & 7 & 298 & Kentucky & & 13 \\
\hline Massachusetts & 34 & 1,146 & Michigan & & 24 \\
\hline Colorado & 16 & 250 & Rhode Island & & 9 \\
\hline New York & & 85 & Arkansas & & 14 \\
\hline Minnesota & 2 & 46 & North Carolina & & 14 \\
\hline Utah & 3 & 48 & Montana & & 7 \\
\hline Washington & & 40 & Florida & & 16 \\
\hline Illinois & & 62 & Hawaii & & 6 \\
\hline Nevada & & 28 & Indiana & & 21 \\
\hline Texas & 14 & 70 & Missouri & 1 & 19 \\
\hline Oregon & 3 & 21 & South Carolina & & 4 \\
\hline Wisconsin & & 28 & Vermont & & 4 \\
\hline Connecticut & & 20 & DC & & 4 \\
\hline Iowa & & 17 & Kansas & & 9 \\
\hline Maryland & & 23 & Alaska & & 2 \\
\hline Maine & & 8 & Tennessee & & 10 \\
\hline New Jersey & & 14 & New Hampshire & & 5 \\
\hline Ohio & 2 & 28 & South Dakota & & 3 \\
\hline Pennsylvania & & 26 & Delaware & & 3 \\
\hline Virginia & & 20 & Wyoming & & 5 \\
\hline North Dakota & & 7 & Louisiana & & 13 \\
\hline New Mexico & & 10 & West Virginia & 1 & 2 \\
\hline Georgia & & 18 & Mississippi & & 1 \\
\hline Oklahoma & & 4 & Foreign & & 26 \\
\hline
\end{tabular}

Note: This table lists the number of competitions and unique ventures by state. Companies that changed states are assigned their earliest state. 
Table A.5: Unconditional association between characteristics and success

\begin{tabular}{|c|c|c|c|c|}
\hline \multirow[t]{2}{*}{ Dependent Variable: } & \multicolumn{2}{|c|}{ Financing after round } & \multicolumn{2}{|c|}{$\geq 10$ employees as of $8 / 2016$} \\
\hline & $(1)$ & $(2)$ & (3) & (4) \\
\hline \multirow[t]{2}{*}{ Founder student at round } & -.023 & .016 & .029 & .043 \\
\hline & $(.047)$ & $(.028)$ & $(.042)$ & $(.028)$ \\
\hline \multirow[t]{2}{*}{ Founder top 10 college } & $.061 *$ & $.051 * * *$ & .035 & .032 \\
\hline & $(.035)$ & $(.018)$ & $(.037)$ & $(.022)$ \\
\hline \multirow[t]{2}{*}{ Founder has MBA } & -.052 & -.0095 & -.061 & $-.054 * * *$ \\
\hline & $(.034)$ & $(.017)$ & $(.038)$ & $(.018)$ \\
\hline \multirow[t]{2}{*}{ Founder top $10 \mathrm{MBA}$} & -.034 & -.029 & .042 & .028 \\
\hline & $(.041)$ & $(.021)$ & $(.046)$ & $(.023)$ \\
\hline \multirow[t]{2}{*}{ Venture age $>$ median } & -.023 & & .0091 & \\
\hline & $(.028)$ & & $(.025)$ & \\
\hline \multirow[t]{2}{*}{ Venture in VC hub state } & $.093 * *$ & $.088 * * *$ & $.057^{*}$ & $.09 * * *$ \\
\hline & $(.038)$ & $(.018)$ & $(.034)$ & $(.019)$ \\
\hline \multirow[t]{2}{*}{ Financing before round } & $.088 * *$ & $.19 * * *$ & $.15^{* * *}$ & $.16^{* * *}$ \\
\hline & $(.038)$ & $(.028)$ & $(.036)$ & $(.023)$ \\
\hline \multirow[t]{2}{*}{ Venture incorp. at round } & -.0049 & .021 & .033 & $.07 * * *$ \\
\hline & $(.036)$ & $(.018)$ & $(.032)$ & $(.017)$ \\
\hline \multirow[t]{2}{*}{ Founder \# jobs before round } & $.029 * * *$ & $.014 * * *$ & $.023^{* * *}$ & $.0091 * * *$ \\
\hline & $(.0056)$ & $(.0027)$ & $(.0059)$ & $(.0026)$ \\
\hline \multirow[t]{2}{*}{ Founder age $>$ median } & -.02 & & $-.063 * *$ & \\
\hline & $(.029)$ & & $(.031)$ & \\
\hline \multirow[t]{2}{*}{ Venture social/ clean tech } & $-.14 * * *$ & $-.13 * * *$ & -.024 & $-.044 * *$ \\
\hline & $(.039)$ & $(.015)$ & $(.047)$ & $(.017)$ \\
\hline \multirow[t]{2}{*}{ Venture Internet/software } & $.14 * * *$ & $.12 * * *$ & $.068^{*}$ & $.074 * * *$ \\
\hline & $(.039)$ & $(.021)$ & $(.038)$ & $(.021)$ \\
\hline \multirow[t]{2}{*}{ Venture \# team members } & $.03^{* *}$ & .0087 & $.035^{* * *}$ & $.017 * * *$ \\
\hline & $(.014)$ & $(.0063)$ & $(.01)$ & $(.0058)$ \\
\hline $\mathrm{N}$ & 1184 & 3346 & 1184 & 3346 \\
\hline$R^{2}$ & .072 & .1 & .06 & .061 \\
\hline
\end{tabular}

Note: This table contains the unconditional association of characteristics and success, using the OLS regression: $Y_{i}^{\text {Post }}=\alpha+\beta^{\prime} \mathbf{C}_{i}+\varepsilon_{i, j}$ where $\mathbf{C}$ is a vector of characteristics. Standard errors clustered by competition-round. Columns 2 and 4 have a much larger sample because they omit venture and founder age, which are not available for many ventures. 


\section{Table A.6: Representativeness of Sample}

\begin{tabular}{lccc}
\hline \multicolumn{5}{c}{ Panel 1: Venture Sectors } & & \\
& & & \\
& $\%$ ventures in data & $\%$ U.S. VC deals & $\%$ U.S. VC deal amt \\
Air/water/waste/agriculture & $3.9 \%$ & & \\
Biotech & $4.8 \%$ & $10.8 \%$ & $12.9 \%$ \\
Clean tech/renewable energy & $18.9 \%$ & $3.3 \%$ & $2.0 \%$ \\
Defense/security & $1.7 \%$ & & \\
Education & $1.0 \%$ & & \\
Energy (fossil) & $1.6 \%$ & & \\
Fintech/financial & $1.4 \%$ & $1.9 \%$ & \\
Food/beverage & $2.3 \%$ & & \\
Health (ex biotech) & $7.2 \%$ & $8.1 \%$ \\
IT/software/web & $37.2 \%$ & $40.4 \%$ & $6.0 \%$ \\
Manuf./materials/electronics & $8.6 \%$ & $7.4 \%$ & $8.0 \%$ \\
Media/ads/entertainment & $1.5 \%$ & $9.6 \%$ & \\
Real estate & $1.6 \%$ & & \\
Retail/apparel/consumer goods & $3.7 \%$ & $6.8 \%$ & \\
Social enterprise & $1.1 \%$ & & \\
Transportation & $3.6 \%$ & & \\
\hline
\end{tabular}


Panel 2: Venture States (top 20 states in data)

\begin{tabular}{lccc} 
& $\begin{array}{c}\text { \% ventures in } \\
\text { data }\end{array}$ & $\begin{array}{c}\% \text { U.S. VC deals } \\
\text { Massachusetts }\end{array}$ & $\begin{array}{c}\text { U.S V deal } \\
\text { amt }\end{array}$ \\
Arizona & $35.5 \%$ & $9.7 \%$ & $9.6 \%$ \\
California & $20.6 \%$ & $0.6 \%$ & $0.2 \%$ \\
Colorado & $9.2 \%$ & $40.6 \%$ & $57.3 \%$ \\
New York & $7.8 \%$ & $2.0 \%$ & $1.3 \%$ \\
Texas & $2.6 \%$ & $10.6 \%$ & $10.6 \%$ \\
Illinois & $2.2 \%$ & $3.7 \%$ & $2.0 \%$ \\
Utah & $1.9 \%$ & $2.2 \%$ & $1.9 \%$ \\
Minnesota & $1.5 \%$ & $1.3 \%$ & $1.2 \%$ \\
Washington & $1.4 \%$ & $0.7 \%$ & $0.6 \%$ \\
Nevada & $1.2 \%$ & $2.6 \%$ & $2.0 \%$ \\
Wisconsin & $0.9 \%$ & $0.1 \%$ & $0.0 \%$ \\
Ohio & $0.9 \%$ & $0.5 \%$ & $0.2 \%$ \\
Pennsylvania & $0.9 \%$ & $1.6 \%$ & $0.4 \%$ \\
Michigan & $0.8 \%$ & $4.6 \%$ & $1.1 \%$ \\
Maryland & $0.7 \%$ & $0.1 \%$ & $0.6 \%$ \\
Oregon & $0.7 \%$ & $1.6 \%$ & $1.5 \%$ \\
Indiana & $0.7 \%$ & $1.0 \%$ & $0.4 \%$ \\
Connecticut & $0.7 \%$ & $0.4 \%$ & $0.1 \%$ \\
Virginia & $0.6 \%$ & $1.3 \%$ & $0.8 \%$ \\
\hline \hline & $0.6 \%$ & $1.7 \%$ & $0.7 \%$ \\
\hline
\end{tabular}

Note: This table compares the frequency of ventures in this sample with U.S. VC deals from the National Venture Capital Association's 2016 Yearbook. 